\section{CONTRACTOR REPORT}

SAND93-7094

Unlimited Release

UC -630
$1-4-94$ MS 0100

DOCUMENT PROCESSING FOR

DOE/OSTI, 7613-2

\title{
Air Quality Investigations of the Sandia National Laboratories Sol se Mete Aerial Cable Facility
}

William M. Gutman and Robert J. Silver

Physical Science Laboratory

Now Mexico State University

Box 30002

Las Cruces, New Mexico 88003

Prepared by Sandia National Laboratories Albuquerque. New Mexico 87185 and Livermore, California 94550 for the United States Department of Energy under Contract DE-AC04-94AL85000

Approved for public release; distribution is unlimited.

Printed December 1994

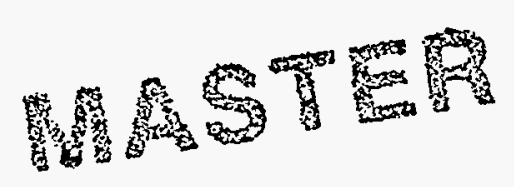


Issued by Sandia National Laboratories, operated for the United States Department of Energy by Sandia Corporation.

NOTICE: This report was prepared as an account of work sponsored by an agency of the United States Government. Neither the United States Government nor any agency thereof, nor any of their employees, nor any of their contractors, subcontractors, or their employees, makes any warranty, express or implied, or assumes any legal liability or responsibility for the accuracy, completeness, or usefulness of any information, apparatus, product, or process disclosed, or represents that its use would not infringe privately owned rights. Reference herein to any specific commercial product, process, or service by trade name, trademark, manufacturer, or otherwise, does not necessarily constitute or imply its endorsement, recommendation, or favoring by the United States Government, any agency thereof or any of their contractors or subcontractors. The views and opinions expressed herein do not necessarily state or reflect those of the United States Government, any agency thereof or any of their contractors.

Printed in the United States of America. This report has been reproduced directly from the best available copy.

Available to DOE and DOE contractors from

Office of Scientific and Technical Information

PO Box 62

Oak Ridge, TN 37831

Prices available from (615) 576-8401, FTS 626-8401

Available to the public from

National Technical Information Service

US Department of Commerce

5285 Port Royal Rd

Springfield, VA 22161

NTIS price codes

Printed copy: A05

Microfiche copy: A01 


\section{DISCLAIMER}

Portions of this document may be illegible in electronic image products. Images are produced from the best available original document. 


\section{CONTRACTOR REPORT}

SAND93 - 7094

Unlimited Release

$\mathrm{UC}-630$

\section{AIR QUALITY INVESTIGATIONS OF THE SANDIA NATIONAL LABORATORIES SOL SE METE AERIAL CABLE FACILITY}

William M. Gutman

Robert J. Silver

Physical Science Laboratory

New Mexico State University

Box 30002

Las Cruces, New Mexico 88003

Prepared by Sandia National Laboratories, Albuquerque, New Mexico 87185 and Livermore, California 94550 for the United States Department of Energy under Contract 4812

Printed December 1994

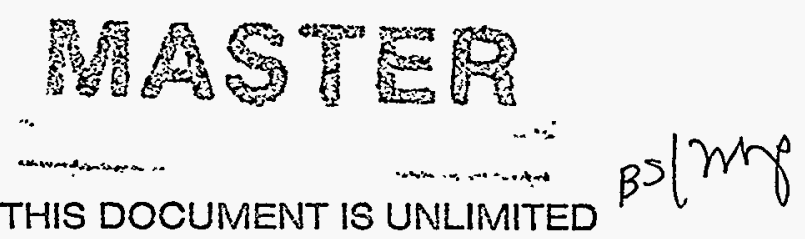


SAND93 - 7094

Unlimited Release

Printed December 1994

Distribution

Category UC - 630

\title{
AIR QUALITY INVESTIGATIONS \\ OF THE SANDIA NATIONAL LABORATORIES \\ SOL ST METE AERIAL CABLE FACILITY
}

\author{
William M. Gutman \\ Robert J. Silver \\ Physical Science Laboratory \\ New Mexico State University \\ Box 30002 \\ Las Cruces, New Mexico 88001
}

\author{
Prepared for \\ Department 2761 \\ Energetic and Environmental Testing Department \\ and \\ Department 7258 \\ Risk Management and NEPA Department \\ Task Leader: Theodore A. Wolff \\ Sandia Contract 4812
}

\begin{tabular}{|l||}
\hline Abstract \\
The air quality implications of the test and evaluation activities at the Sandia National \\
Laboratories Sol se Mete Aerial Cable Facility are examined. All facets of the activity that affect \\
air quality are considered. Air contaminants produced directly include exhaust products of rocket \\
motors used to accelerate test articles, dust and gas from chemical explosives, and exhaust gases \\
from electricity generators in the test arenas. Air contaminants produced indirectly include fugitive \\
dust and exhaust contaminants from vehicles used to transport personnel and material to the test \\
area, and effluents produced by equipment used to heat the project buildings. Both the ongoing \\
program and the proposed changes in the program are considered. Using a reliable estimate of the \\
maximum annual testing level, the quantities of contaminants released by project activities are \\
computed either from known characteristics of test items or from EPA-approved emission factors. \\
Atmospheric concentrations of air contaminants are predicted using EPA dispersion models. The \\
predicted quantities and concentrations are evaluated in relation to Federal, New Mexico, and \\
Bernalillo County air quality regulations and the human health and safety standards of the \\
American Conference of Governmental Industrial Hygienists.
\end{tabular}




\section{TABLE OF CONTENTS}

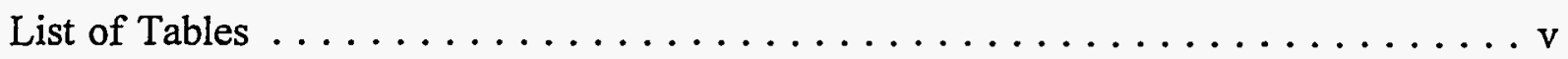

List of Figures $\ldots \ldots \ldots \ldots \ldots \ldots \ldots \ldots \ldots \ldots \ldots \ldots \ldots \ldots \ldots \ldots \ldots \ldots$

List of Abbreviations and Acronyms $\ldots \ldots \ldots \ldots \ldots \ldots \ldots \ldots \ldots \ldots$ ix

Executive Summary $\ldots \ldots \ldots \ldots \ldots \ldots \ldots \ldots \ldots \ldots \ldots \ldots \ldots \ldots \ldots$

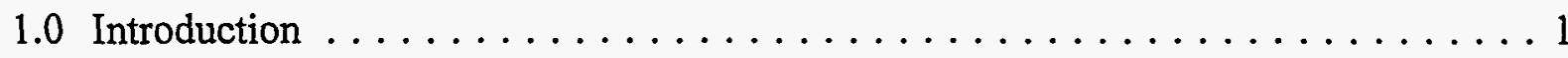

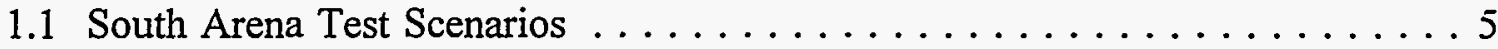

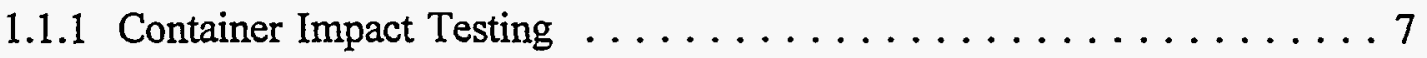

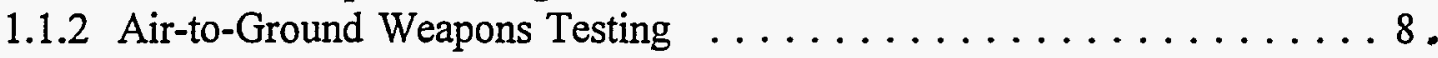

1.2 Specialized Support Operations $\ldots \ldots \ldots \ldots \ldots \ldots \ldots \ldots \ldots \ldots$

1.3 ACF Sled Track .......................... 9

1.4 North Arena Test Scenarios . . . . . . . . . . . . . . . 11

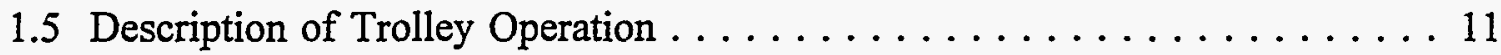

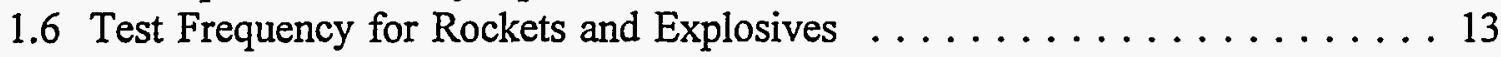

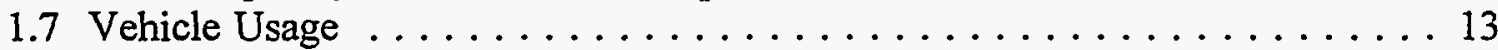

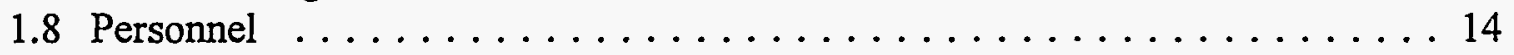

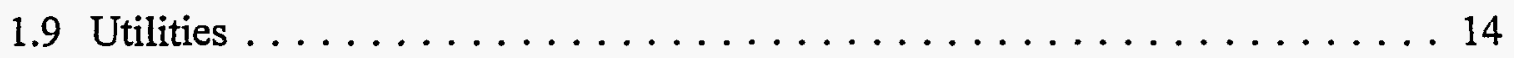

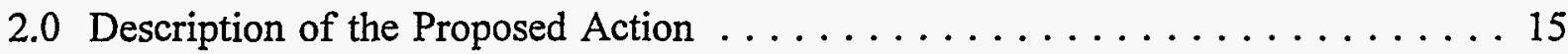

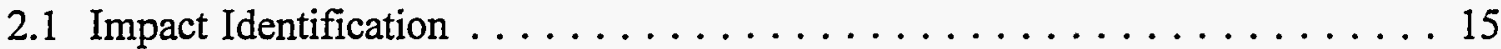

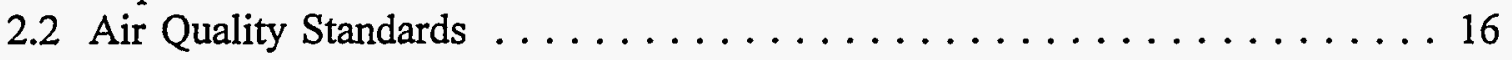

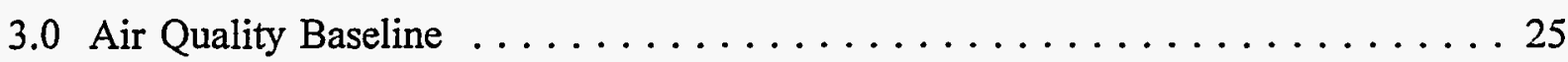

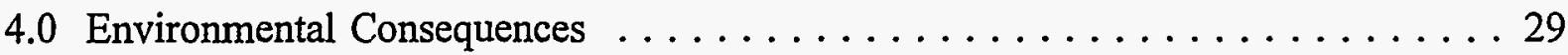

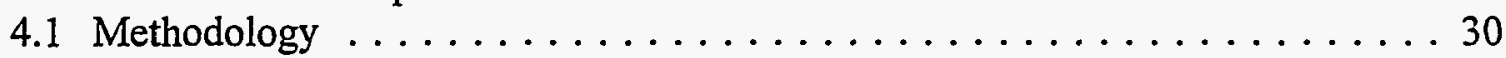

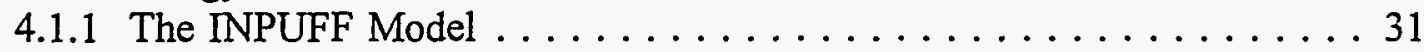

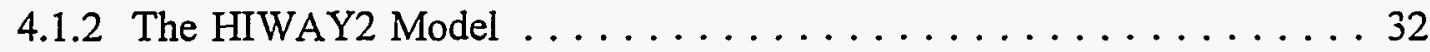

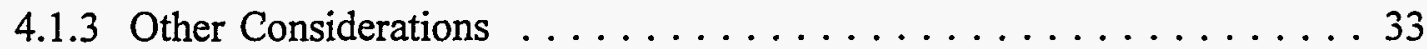

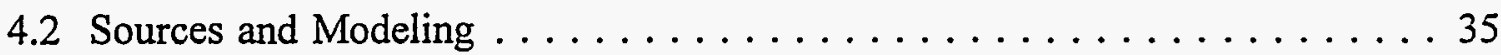

4.2 .1 Booster Rocket Motors . . . . . . . . . . . . . . . . 35

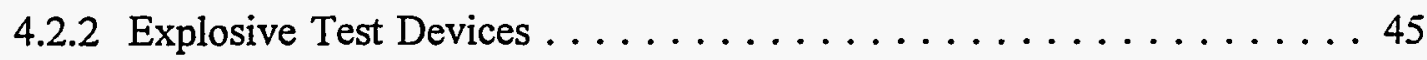

4.2 .3 Contaminants from Vehicle Operations . . . . . . . . . . 50

4.2 .4 Electricity Generators . . . . . . . . . . . . . . . . 60

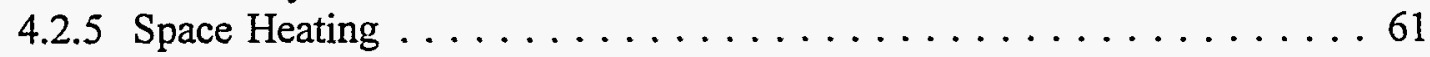

4.2.6 Solvents and Toxic Materials . . . . . . . . . . . . 61

4.2.7 Magnesium Flares . . . . . . . . . . . . . . . 62

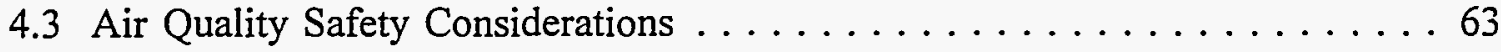

4.3 .1 Hazard Radius . . . . . . . . . . . . . . . . . 64 


\section{TABLE OF CONTENTS \\ (Continued)}

4.3.2 Elapsed Time Until Safe Re-entry . . . . . . . . . . . . 65

4.3.3 Recommendations for Protection of Human Health . . . . . . . 65

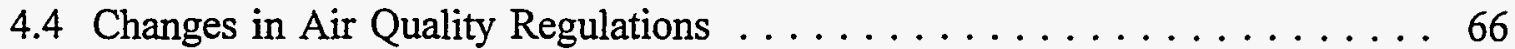

4.5 Summary of Air Quality Impacts at the ACF . . . . . . . . . 66

References ........................... 71 


\section{LIST OF TABLES}

Table ES-1. Total Annual Emissions and Estimated Maximum Concentrations of Atmosphetic Contaminants at the ACF Control Building During

Operation of the ACF .................... ES-iii

Table 1. Standards for Ambient Air Quality ................. 18

Table 2. New Mexico Standards for Significant Emission Rates . . . . . . . . . . . 19

Table 3. New Mexico Standards for Significant Monitoring Concentrations . . . . . . 20

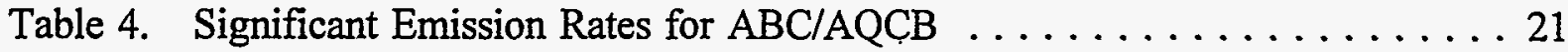

Table 5. Significant Monitoring Standards for $\mathrm{ABC} / \mathrm{AQCB} \ldots \ldots \ldots \ldots \ldots 22$

Table 6. Significant Ambient Standards for ABC/AQCB . . . . . . . . . . 23

Table 7. Occupational Exposure Limits Reduced by a Factor of 100 for Additional Substances at $\mathrm{ACF}$. . . . . . . . . . . . . . 23

Table 8. SNL, Albuquerque, Environmental Monitoring Locations and Sample Type for Radioactive Surveillance . . . . . . . . . . . . . 27

Table 9. Rocket Exhaust Quantities ........................ 36

Table 10. Rocket Exhaust Gas Composition . . . . . . . . . . . . . . 37

Table 11. Pollutant Content of Exhaust of Representative Boosters . . . . . . . . 38

Table 12. Maximum Total Release of Air Contaminants by Booster Motors Used for Trolley Acceleration . . . . . . . . . . . . . . . . . . . 39

Table 13. Maximum Concentrations of Air Contaminants in $\mathrm{g} / \mathrm{m}^{3}$ from Trolley Boosters at Selected Locations In and Near the Test Site . . . . . . . . . 41

Table 14. Maximum Predicted Concentrations of Air Contaminants at the Control Building Resulting from a Cluster of 11 Zuni or HVAR Boosters under $3 \mathrm{~m} / \mathrm{s}$ Wind Conditions .................... 44

Table 15. Maximum Release Scenario Annual Emissions of Air Contaminants Resulting from Trolley and Pull-Down Boosters . . . . . . . . 45

Table 16. Emission Factors for Air Contaminants Produced by High Explosives and Estimated Total Annual Emissions . . . . . . . . . . . . . . 46

Table 17. Predicted Initial Concentrations of Air Contaminants and Potential 8-hour Time Weighted Average Exposure Levels . . . . . . . . . 48

Table 18. Predicted Average Concentrations of Air Contaminants at the ACF Control Building Resulting from Sustained 3-Round per Hour Firing of the 3 -inch Gun under $3 \mathrm{~m} / \mathrm{s}$ Wind Conditions . . . . . . . . . 48

Table 19. Predicted Average Concentrations of Air Contaminants at the ACF Control Building Resulting from a 454-kg (1,000-1b) Explosive Device Under $3 \mathrm{~m} / \mathrm{s}$ Wind Conditions ....................... 50

Table 20. Lengths of Paved and Unpaved Road Segments Associated with

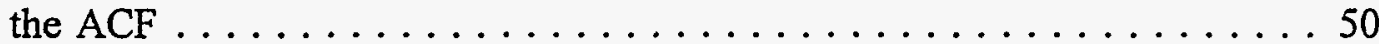

Table 21. Estimated Vehicular Traffic Associated with Operation of the ACF . . . . 51

Table 22. Assumed Vehicle Characteristics . . . . . . . . . . . . . . 51

Table 23. Computed Emission Factors for Fugitive Dust . . . . . . . . . . . 53

Table 24. Standard EPA Exhaust Emission Factors Based on High Altitude 1990 Standards . . . . . . . . . . . . . . . . . . . . 54 


\section{LIST OF TABLES \\ (Continued)}

Table 25. Annual Air Contaminant Emissions Due to Operation of Vehicles

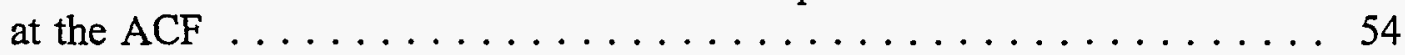

Table 26. Emission Rates of Vehicle-Produced Air Contaminants and Wind-Produced Fugitive Dust . . . . . . . . . . . . . . . . . 57

Table 27. Distance from the Roads at which Concentrations Drop to the New Mexico Significant Ambient Concentration Level . . . . . . . . . . . . . . 59

Table 28. Emission Factors for Stationary Large-Bore Diesel Engines and Estimated Annual Emissions and Average Concentrations at the Control Building . . 60

Table 29. Air Contaminants Produced by Space Heating at the ACF . . . . . . . 61

Table 30. Total Annual Emissions of Atmospheric Contaminants During ACF Operation ...................... 68

Table 31. Maximum Concentrations of Atmospheric Contaminants During ACF Operation for Appropriate Averaging Periods at the Control Building . . . 68

Table 32. Total Annual Emissions and Estimated Maximum Concentrations of Atmospheric Contaminants at the ACF Control Building During Operation of the ACF .............................. 69 


\section{LIST OF FIGURES}

Figure 1. Project Location near Albuquerque, NM . . . . . . . . . . . 2

Figure 2. Kirtland Air Force Base and Sandia National Laboratories Test Areas . . . . 3

Figure 3. Aerial Photograph of SNL Aerial Cable Facility $\ldots \ldots \ldots \ldots \ldots \ldots$

Figure 4. View of South Arena from West Anchor Site . . . . . . . . . . 6

Figure 5. Rocket-Assisted Pull-Down Technique for a Side Impact . . . . . . . . 10

Figure 6. North Arena, SNL Aerial Cable Facility ................ 12

Figure 7. Monitoring Locations in Technical Areas I through V and Kirtland AFB . 26

Figure 8. One-Hour Average Carbon Monoxide Concentration Contours $\left(\mathrm{g} / \mathrm{m}^{3}\right)$; Wind Speed $1 \mathrm{~m} / \mathrm{s}$ (for 25 Zuni motors used for trolley acceleration) . . . . . . 42

Figure 9. One-Hour Average Carbon Monoxide Concentration Contours $\left(\mathrm{g} / \mathrm{m}^{3}\right)$; Wind Speed $3 \mathrm{~m} / \mathrm{s}$ (for 25 Zuni motors used for trolley acceleration) . . . . . 43 
This page intentionally left blank. 


\section{LIST OF ABBREVIATIONS AND ACRONYMS}

\begin{tabular}{|c|c|}
\hline $\begin{array}{l}\mathrm{ABC} / \mathrm{AQCB} \\
\mathrm{ACF}\end{array}$ & Albuquerque/Bernalillo County Air Quality Control Board \\
\hline $\mathrm{ACF}$ & Aerial Cable Facility \\
\hline ACGIH & American Conference of Governmental Industrial Hygienists \\
\hline AFB & Air Force Base \\
\hline $\mathrm{Al}_{2} \mathrm{O}_{3}$ & aluminum oxide \\
\hline Bldg. & building \\
\hline BTU & British thermal unit \\
\hline CFR & Code of Federal Regulations \\
\hline $\mathrm{CH}_{4}$ & methane \\
\hline $\mathrm{cm}$ & centimeter \\
\hline $\mathrm{CO}$ & carbon monoxide \\
\hline $\mathrm{CO}_{2}$ & carbon dioxide \\
\hline ConWep & Conventional Weapons Effects Model \\
\hline $\mathrm{CuO}$ & copper oxide \\
\hline DOD & Department of Defense \\
\hline DOE & Department of Energy \\
\hline EA & Environmental Assessment \\
\hline EPA & Environmental Protection Agency (Federal) \\
\hline fps & feet per second \\
\hline $\mathrm{ft}$ & foot or feet \\
\hline $\mathrm{ft}^{2}$ & square foot or square feet \\
\hline $\mathrm{ft}^{3}$ & cubic foot or cubic feet \\
\hline $\mathrm{g} / \mathrm{m}^{3}$ & grams per cubic meter \\
\hline gal & gallon \\
\hline GHA & Ground Hazard Area \\
\hline $\mathrm{H}_{2}$ & molecular hydrogen \\
\hline $\mathrm{H}_{2} \mathrm{O}$ & water \\
\hline $\mathrm{H}_{2} \mathrm{~S}$ & hydrogen sulfide. \\
\hline HARC & Helicopter Accident Resistant Container \\
\hline $\mathrm{HC}$ & hydrocarbons \\
\hline $\mathrm{HCl}$ & hydrogen chloride \\
\hline $\mathrm{HCN}$ & hydrogen cyanide \\
\hline HIWAY2 & Highway Air Pollution Model \\
\hline hr & hour \\
\hline $\begin{array}{l}\text { HVAR } \\
\text { in }\end{array}$ & $\begin{array}{l}\text { High Velocity Aircraft Rocket } \\
\text { inch }\end{array}$ \\
\hline INPUFF & Integrated Puff Multiple Source Gaussian Dispersion Model \\
\hline $\mathrm{K}_{2} \mathrm{O}$ & potassium oxide \\
\hline KAFB & Kirtland Air Force Base \\
\hline kg & kilogram \\
\hline $\mathrm{km}$ & kilometer \\
\hline $\mathrm{KOH}$ & potassium hydrc \\
\hline
\end{tabular}




\section{LIST OF ACRONYMS AND ABBREVIATIONS}

(Continued)

\begin{tabular}{|c|c|}
\hline $\mathrm{kW}$ & kilowatt \\
\hline $\mathrm{lb}$ & pound \\
\hline $\mathrm{m}$ & meter \\
\hline $\mathrm{m} / \mathrm{s}$ & meters per second \\
\hline $\mathrm{m}^{2}$ & square meter(s) \\
\hline $\mathrm{m}^{3}$ & cubic meter(s) \\
\hline $\mathrm{mg}$ & milligram \\
\hline $\mathrm{MgO}$ & magnesium oxide \\
\hline $\mathrm{mi}$ & mile \\
\hline $\mathrm{mm}$ & millimeter \\
\hline $\mathrm{mph}$ & miles per hour \\
\hline $\mathrm{N}_{2}^{2}$ & molecular nitrogen \\
\hline NAAQS & National Ambient Air Quality Standards \\
\hline $\mathrm{NH}_{3}$ & ammonia \\
\hline NM/AQCR & New Mexico/Air Quality Control Regulations \\
\hline $\mathrm{NMHC}$ & nonmethane hydrocarbons \\
\hline $\mathrm{NO}_{x}$ & nitrogen oxides \\
\hline $\mathrm{O}_{3}$ & ozone \\
\hline OEL & occupational exposure limit \\
\hline OSHA & Occupational Safety and Health Administration \\
\hline PAT & Plutonium Air Transportable \\
\hline $\mathrm{Pb}$ & lead \\
\hline $\mathrm{PM}_{10}$ & $\begin{array}{l}\text { particles with aerodynamic diameter less than or equal to a } \\
\text { nominal } 10 \mu \mathrm{m}\end{array}$ \\
\hline ppm & parts per million (by volurne) \\
\hline s & second \\
\hline SNL & Sandia National Laboratories \\
\hline $\mathrm{SO}_{2}$ & sulfur dioxide \\
\hline $\mathrm{SO}_{x}$ & sulfur oxides \\
\hline STEL & Short Term Exposure Limit \\
\hline TA-III & Technical Area III \\
\hline TLD & thermoluminescent dosimeters \\
\hline TLV & Threshold Limit Value \\
\hline TSC-V & Transportation Safety Container-Variant \\
\hline TSP & total suspended particulates \\
\hline TWA & time-weighted average \\
\hline VOC & volatile organic compounds \\
\hline & microgram \\
\hline$\mu \mathrm{g} / \mathrm{m}^{3}$ & micrograms per cubic meter \\
\hline$\mu \mathrm{g} / \mathrm{m} / \mathrm{s}$ & micrograms per meter per second \\
\hline
\end{tabular}




\section{EXECUTIVE SUMMARY}

This document is an assessment of the air quality effects of the operation of the Sandia National Laboratories (SNL) Sol se Mete Aerial Cable Facility (ACF). The ACF is an existing facility, and proposed improvements would have minimal affect on air emissions. Federal, New Mexico, and Bernalillo County air quality standards and regulations apply to this facility.

Baseline measurements of air quality have not been conducted near the ACF either by SNL or by the Albuquerque/Bernalillo County Air Quality Control Board ( $\mathrm{ABC} / \mathrm{AQCB}$ ). Bernalillo County is a noncompliance area for carbon monoxide (CO). Most of the $\mathrm{CO}$ originates within the City of Albuquerque, and the prevailing winds carry most of it away from the ACF. It is reasonable to expect that the air quality at the ACF is similar to that in the surrounding semi-rural areas.

The major sources of air contaminants considered in this document include rocket motors, chemical explosives, vehicle and generator engines, fugitive dust from vehicle operations on unpaved roads, wind acting on unpaved roads and disturbed areas, and space heating. Annual testing level scenarios were developed based on a synthesis of historical test rate information and projections of recent trends. Annual emission quantities were computed using these scenarios and either engineering knowledge about test apparatus, e.g., rocket motors, or EPAapproved emission factors. Concentrations of air contaminants were computed using either of two U.S. Environmental Protection Agency (EPA) air dispersion models: Highway Air Pollution Model (HIWAY2) for road-related emissions and Integrated Puff Multiple Source Gaussian Dispersion Model (INPUFF) for all other requirements. For all the concentration modeling, the height above ground for which model calculations were performed was selected to represent the "breathing zone" of an average person. INPUFF was used for most of the modeling because it allows realistic simulation of the spatial and temporal characteristics of the source. Both models predict the average concentration of a contaminant over a userspecified time interval for user-specified spatial positions. For a uniform line source, 
HIWAY2 predicts the concentration as a function of the perpendicular distance from the source. For the general source modeling using INPUFF, calculations were performed for 100 spatial points, the maximum allowed by the program. The points were selected to ensure inclusion of the highest concentration levels within the modeling region. The two-dimensional output array then was used with a contouring program to generate concentration contours for pertinent averaging times. The resulting contours were plotted on a site base map to show their spatial relationship with the project facilities and other pertinent features.

The results of the analysis are summarized in Table ES-1. This table presents the total annual production of air contaminants and their predicted maximum concentrations at the $\mathrm{ACF}$ Control Building that would result from test activities. The table also contains the New Mexico Significant Emission Rates and Significant Monitoring Concentrations for comparison. The Significant Emission Rate is the threshold annual emission rate at which regulatory requirements for monitoring and Prevention of Significant Deterioration increments begin to apply for major new or modified stationary sources of air contaminants. The Significant Monitoring Concentration is the threshold concentration of an air contaminant released by a major new or modified stationary source above which monitoring requirements cannot be waived by the New Mexico Environment Department. The ACF is neither a major source as defined by the regulations, nor a new or modified source. Nevertheless, these levels are a useful guideline to judge the significance of the ACF in relation to other sources. All annual quantities are far below the Significant Emission Rates, and all predicted concentrations are well below New Mexico Significant Monitoring Concentrations for the appropriate averaging period.

The workplace safety implications of the use of rocket motors and the occasional firing of inert rounds from a 3 -inch gun also were examined. Modeling was conducted for maximum rocket utilization scenarios and with meteorological conditions that would generate the highest average air contaminant concentrations. Also, very conservative safety criteria were used. For rocket accelerated trolley operations, this analysis indicates that the air contaminant concentrations would never exceed the safety criteria at ground level. For pull-down 
operations using the rocket sled track, the air quality safety radius is smaller than the Ground Hazard Area (GHA) that is specified to protect workers from mechanical injury during rocket operations. Additional modeling was used to develop safety criteria for re-entry into the immediate rocket sled track area after a test using the maximum number of boosters for a pull-down test. For a wind speed less than 1.0 meters per second $(\mathrm{m} / \mathrm{s})[3.3$ feet per second (fps)], personnel should be prohibited from areas within 70 meters $(\mathrm{m})$ [230 feet $(\mathrm{ft})]$ of the rocket sled track for 15 minutes after the test. The 3-inch gun releases some lead when fired. Analysis of the situation indicates that the maximum 8-hour time-weighted average lead concentration that workers could be exposed to is less than half the applicable standards.

- Table ES-1. Total Annual Emissions and Estimated Maximum Concentrations of Atmospheric Contaminants at the ACF Control Building During Operation of the ACF

\begin{tabular}{|lccc|cc|}
\hline & NM Significant & & \multicolumn{2}{c|}{ ACF Estimated } \\
\cline { 5 - 6 } \multicolumn{1}{c}{ Contaminant } & $\begin{array}{c}\text { Emission Rate } \\
\text { (tons/year) }\end{array}$ & $\begin{array}{c}\text { Concentration } \\
\left(\mu \mathrm{g} / \mathrm{m}^{3}\right)\end{array}$ & $\begin{array}{c}\text { Averaging } \\
\text { Time }\end{array}$ & $\begin{array}{c}\text { Total } \\
\text { Emission } \\
(\text { tons/yr) }\end{array}$ & $\begin{array}{c}\text { Maximum } \\
\text { Concentration } \\
\left(\mu \mathrm{g} / \mathrm{m}^{3}\right)^{\mathrm{s}}\end{array}$ \\
\hline Carbon monoxide & 100 & 575 & 8 hours & 5.9 & 22.1 \\
Hydrocarbons & 40 & $-\mathrm{b}-$ & 3 hours & 0.16 & 4.0 \\
Nitrogen oxides & 40 & 14 & 24 hours & 2.1 & 2.4 \\
Total suspended & & & & & \\
$\quad$ particulates & 25 & 10 & 24 hours & $5.8^{\mathrm{f}}$ & 5.2 \\
Sulfur oxides & 40 & 13 & 3 hours & $0.29^{\mathrm{c}}$ & 1.4 \\
Hydrogen cyanide & $-\mathrm{d}-$ & $100^{\mathrm{e}}$ & 8 hours & 0.018 & 0.50 \\
Lead & 0.6 & 0.1 & 3 months & 0.011 & 0.00081 \\
Potassium hydroxide & $-\mathrm{d}-$ & $20^{\mathrm{e}}$ & 8 hours & $0.063^{\mathrm{g}}$ & 0.16 \\
Ammonia & $-\mathrm{d}-$ & $180^{\mathrm{e}}$ & 8 hours & 0.019 & 0.54 \\
\hline
\end{tabular}

a As predicted by INPUFF at the Control Building for $3 \mathrm{~m} / \mathrm{s}$ winds for the maximum concentration direction, except that total suspended particulates are predicted for $50 \mathrm{~m}$ from the road.

b No specific concentration specified. Three-hour significant ambient concentration in New Mexico/Air Quality Control Regulation (NM/AQCR) 702 is $5 \mu \mathrm{g} / \mathrm{m}^{3}$.

c No acceptable monitoring technique is available.

d Not a criteria pollutant. No significant emission rate established.

e No concentration specified. The 8-hour limit is taken to be $1 / 100$ of the occupational exposure limit (OEL) as specified in NM/AQCR 702.

f Also includes maximum contaminant release scenario emission of nongaseous contaminants by booster rockets.

g Maximum contaminant release scenario emission. 
This page intentionally left blank. 


\subsection{INTRODUC்TION}

Sandia National Laboratories (SNL) operates the Sol se Mete Aerial Cable Facility (ACF) at Kirtland Air Force Base (KAFB), New Mexico, for the Department of Energy (DOE). The $\mathrm{ACF}$ is located on the eastern portion of KAFB. It is situated within Cibola National Forest on land withdrawn under a 1967 agreement between the U.S. Air Force and the U.S. Forest Service. Subsequently, a portion of the land was placed under DOE control for use by the ACF under a supplemental agreement between DOE and KAFB. The ACF is located within an area known as the Coyote Test Field.

The ACF consists of a test area where a series of cables are suspended across Sol se Mete Canyon. The cable systems are used to suspend test articles for ground impact tests under controlled acceleration conditions. Gravitational acceleration is used to achieve test article impact velocities of up to 46 meters per second $(\mathrm{m} / \mathrm{s})$ [150 feet per second (fps)]. Impact velocities up to $244 \mathrm{~m} / \mathrm{s}$ (800 fps) can be achieved through a rocket sled pull-down towing technique. The cable also is used as a tramway for moving trolleys that support targets used for testing a variety of passive and active electronic, optical tracking, and acquisition devices.

Presently, one heavy steel cable and one Kevlar cable are used in the South Test Arena, and two lighter steel cables are used in the North Arena. The two test arenas are located approximately 305 meters $(\mathrm{m})[1,000$ feet $(\mathrm{ft})]$ apart on the canyon floor.

Figures 1 and 2 define the geographical location of the ACF. Figure 3 is an aerial photograph of the ACF, labeled to show significant structures. 
†66I دәquวə) $0 \varepsilon$

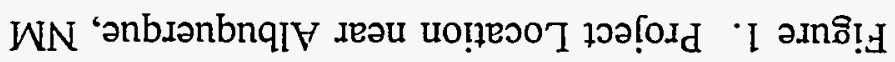

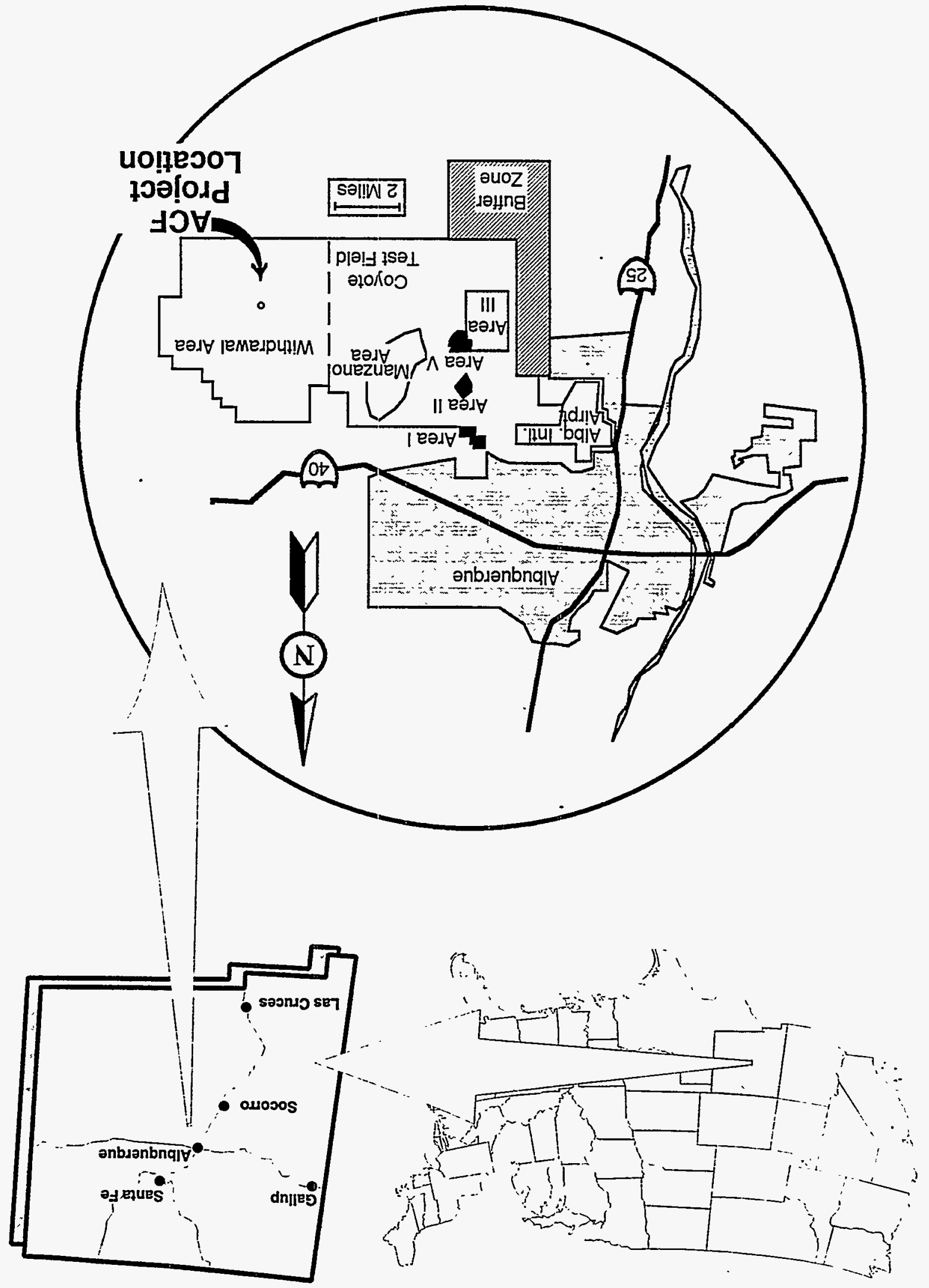




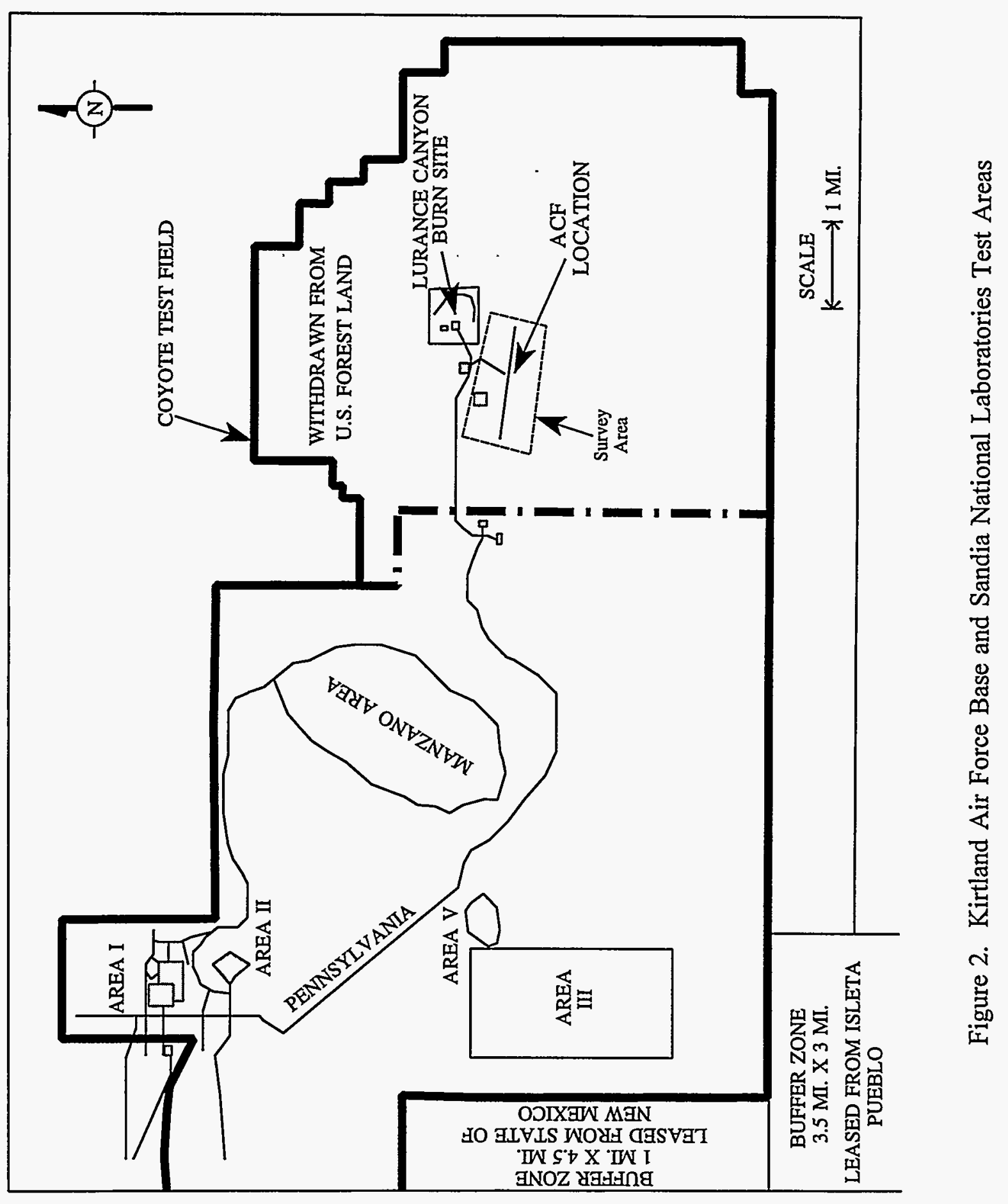




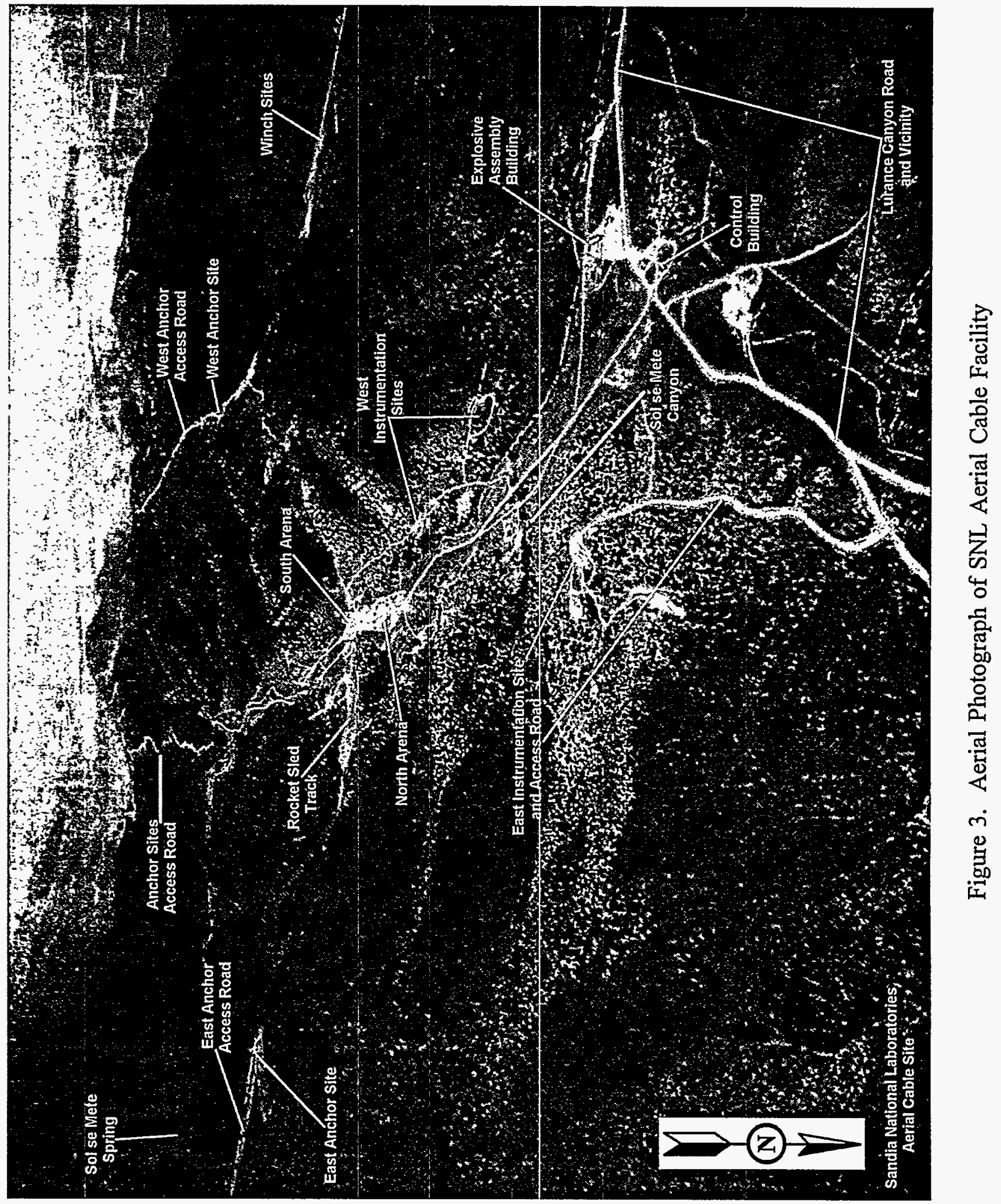


The ACF fulfills multiple purposes in support of DOE research and development activities listed below. These purposes are discussed in greater detail in this section. ACF test activities include the following:

- Precision impact certification testing of nuclear material shipping containers in accordance with Title 10 Part 71 of the Code of Federal Regulations (10 CFR Part 71).

- Precision testing of full-scale, air-delivered weapons tests.

- Precision testing of airborne sensors and sensor-fuzed weapons systems released from a stable aerial platform located above ground targets.

- Precision testing of ground-based sensors and target-acquisition devices directed against simulated aircraft and aircraft targets traversing the ACF cableways.

\subsection{SOUTH ARENA TEST SCENARIOS}

The South Arena is the primary test area for impact tests and tests requiring trolley travel along the overhead cables. Presently, one heavy steel cable and one Kevlar cable are used in conjunction with the ACF Sled Track for nuclear material shipping container impact certification testing, and air-to-ground weapon testing. For purposes of impact tests, the South Arena also contains a unique "unyielding target" constructed beneath the $\mathrm{ACF}$ cableway with two million pounds of reinforced concrete below ground level and capped with steel armor plate at ground level.

The ACF South Arena is shown in Figure 4. 


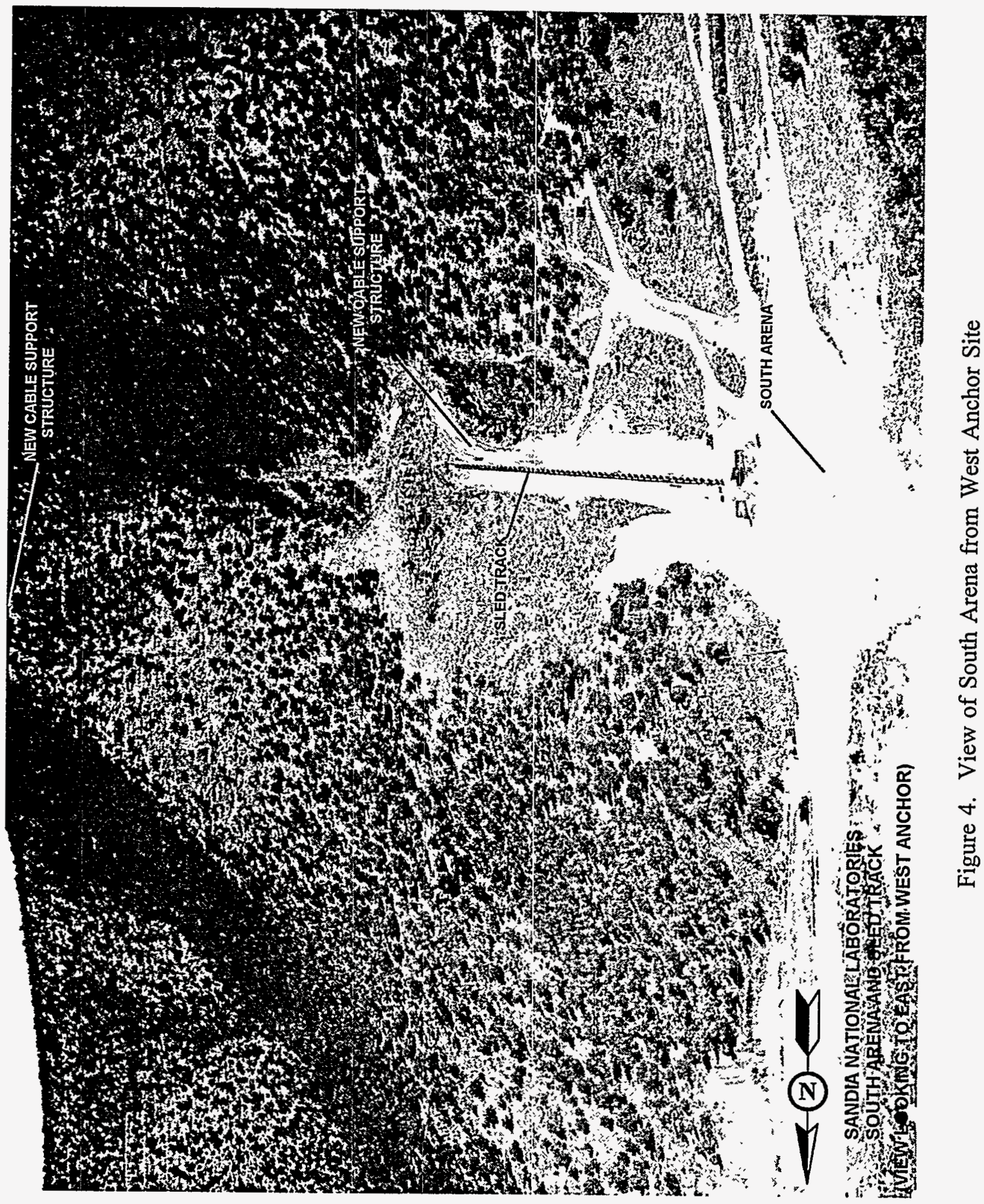




\subsubsection{Container Impact Testing}

In accordance with Title 10 Part 71 of the Code of Federal Regulations (10 CFR Part 71) shipping containers used to transport nuclear materials must be designed to minimize the likelihood of releasing radioactive material in transportation accidents. The ACF is used to demonstrate compliance with impact-related container test provisions of this Federal regulation. The regulations require that the evaluation and certification of containers for transporting radioactive material will be completed by testing the containers under conditions to include impact, puncture, penetration, thermal exposure, water spray, ard immersion.

The ACF is capable of testing large containers weighing up to 90,000 kilogram (kg) (100 tons). Large containers are lifted a few meters above the ground and dropped to achieve impact velocities up to a few meters per second. Smaller containers weighing up to $1,000 \mathrm{~kg}$ ( 1 ton) can be accelerated to impact velocities up to $250 \mathrm{~m} / \mathrm{s}$ (800 fps). Current container impact resistance specifications are largely based upon work that has been performed at the ACF.

Over the past 7 years, 123 container impact test series have relied on the ACF testing facilities in the ACF South Arena (Hohnstreiter et al. 1991). Included in these test programs were tests of the Plutonium Air Transportable (PAT) container, the TRUPACT II container, the Big Rock Point container, the Helicopter Accident Resistant Container (HARC), and Three Mile Island Transportation Systems. The most recent container test programs have been for the certification of the Transportation Safety Container-Variant (TSC-V) and the H1501A HARC. Test articles used in the impact studies conducted in the South Arena are actual shipping containers with mock weapon components.

Since 1987, over 123 tests have been conducted using test articles designed to contain nuclear materials, and over 23 of these test units contained depleted uranium. There have been no recorded incidents of mock weapon components being fractured as a result of test activities, and all radioactive materials have been recovered following each test (Bickel, 1993). 
Therefore, impact tests of transportation containers have successfully confirmed the capabilities of these containers to protect ordnance from damage. Because there are no data indicating any release of radioactive materials from these tests, there is very little likelihood of contamination of the test facility as a result of these tests.

\subsubsection{Air-to-Ground Weapons Testing}

The ACF, by engineering simulation, can match the full range of sub-sonic aircraft speeds for delivering full-scale air-to-ground weapons. Weapons are suspended from the aerial cable and are either dropped free-fall or are "pulled down" by the rocket sled to simulate the appropriate delivery velocity of each weapon. Testing and evaluation using the ACF provide significant advantages over aircraft delivery methods during the early stages of weapons development, when accuracy of the weapon flight profile and impact characteristics are the critical parameters in evaluating weapon design. Additionally, release equipment and weapon separation characteristics can be tested at the ACF prior to entering that portion of the weapon test cycle involving compatibility with the delivery aircraft. At this stage in the weapon development cycle, use of the ACF provides for higher probability of acquiring valid test data using test procedures that are less expensive than attempting to test delivery methods using actual aircraft operations.

\subsection{SPECIALIZED SUPPORT OPERATIONS}

The South Arena also is used for highly specialized testing of the target and scoring system used to test U.S. Navy armaments. The target system, including the projectile missile sensors and scoring protocol, must be certified annually. The target is supported from the aerial cable, and up to 100 inert rounds of $20-\mathrm{mm}$ (millimeter) cannon fire, 120 inert rounds of 3-inch naval gun fire, or other weapons are fired at the target. Sophisticated electronics inside the target are used to sense the miss-distance for the passing rounds. From known trajectories for the projectiles, the test allows calculation of the accuracy of target sensing and electronic equipment. Such tests are normally conducted once per year. 


\subsection{ACF SLED TRACK.}

Based on operational scenarios, up to 35 tests per year involve use of a rail-mounted sled accelerated by rocket motors to attain high velocities. The rocket sled is propelled by a combination of Zuni and High Velocity Aircraft Rocket (HVAR) rocket motors typically totaling about $60 \mathrm{~kg}$ [140 pounds (lb)] of propellant. The primary use of this sled track is to pull down test articles from the aerial cable at predetermined velocities that are greater than can be achieved by gravity acceleration. This capability has been used for more than 20 years in tests of mock nuclear ordnance and shipping containers for impact resistance and performance of weapon systems.

The pull-down testing sequence, as shown in Figure 5, is as follows: A wire rope towing system is used to attach the rocket sled to the test article that is suspended from the aerial cable. Towing lines run horizontally behind the sled for about $60 \mathrm{~m}(200 \mathrm{ft})$, where they turn vertically around high-speed wire rope pulleys. The towing lines continue vertically from 180 to 300 meters $(600-1,000 \mathrm{ft})$, where they attach to the test article that is supported from the aerial cable. Zuni and HVAR motors are used to accelerate the sled and the pull-down apparatus. The test article is released from the cable as rockets are ignited, and the test article is pulled downward at the same rate the sled moves along the sled track. The test article is accelerated at up to 40 times the acceleration of gravity along its downward flight path reaching speeds up to $270 \mathrm{~m} / \mathrm{s}$ [600 miles per hour (mph)] in less than 1 second, and the test article impacts precisely on target.

In 1992, as a maintenance replacement action, the original sled track was replaced by a new track with identical dimensions. 


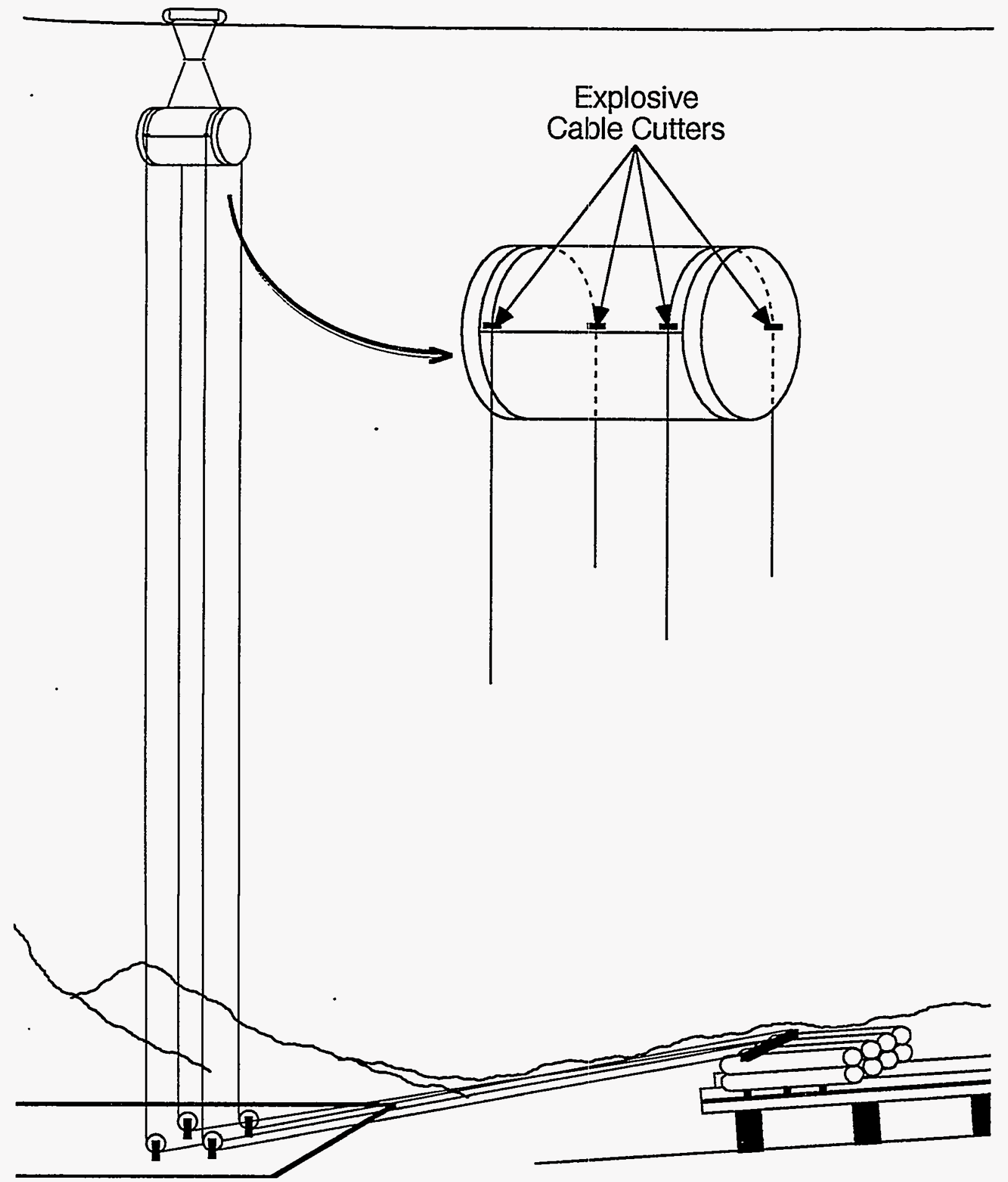

Figure 5. Rocket-Assisted Pull-Down Technique for a Side Impact 


\subsection{NORTH ARENA TEST SCENARIOS}

The ACF North Arena was constructed in 1985. It comprises a separate steel cable system extending from the fixed East Anchor to the West Anchor, and extending down to a winch site that is separated from the winch sites used for the South Arena cable systems. The North Arena cable is steel, with a separate camera cable. One of the cable systems uses anchorages closer to the ground impact area.

This arena is used for engineering simulations involving test articles dropped from the cable onto a target array positioned underneath the cable. In previous tests, up to 16 separate test articles have been dropped against a simulated target array of up to 16 target tanks. In normal tests, the test article packages can range from sensor-only packages to test target acquisition capabilities, to packages using explosive charge devices to allow determination of impact circular error probable. The target array can be a variety of sensor packages or a variety of simulated or actual tactical vehicles.

Figure 6 is an annotated photograph depicting 16 target tanks.

\subsection{DESCRIPTION OF TROLLEY OPERATION}

A maximum of 50 trolley operations are performed per year at the ACF. Each unboosted trolley operation can consist of as many as 10 individual traversals of the cable. The ACF acts as a tramway for trolleys and/or targets that traverse the cable rolling on sheaves. The trolleys are able to achieve velocities on the order of $25 \mathrm{~m} / \mathrm{s}$ ( $80 \mathrm{fps}$ ) if accelerated by gravity from the east end of the ACF. Higher velocities can be reached by rocket boosting the trolleys. Surplus Zuni and HVAR rocket motors are used to accelerate the trolley. Velocities up to $230 \mathrm{~m} / \mathrm{s}$ (750 fps) are anticipated for an estimated ten yearly tests.

The trolley and target can weigh up to $3,175 \mathrm{~kg}(7,000 \mathrm{lb})$. Trolleys are braked by a combination of devices that could include drogue parachutes, restraining devices similar to 


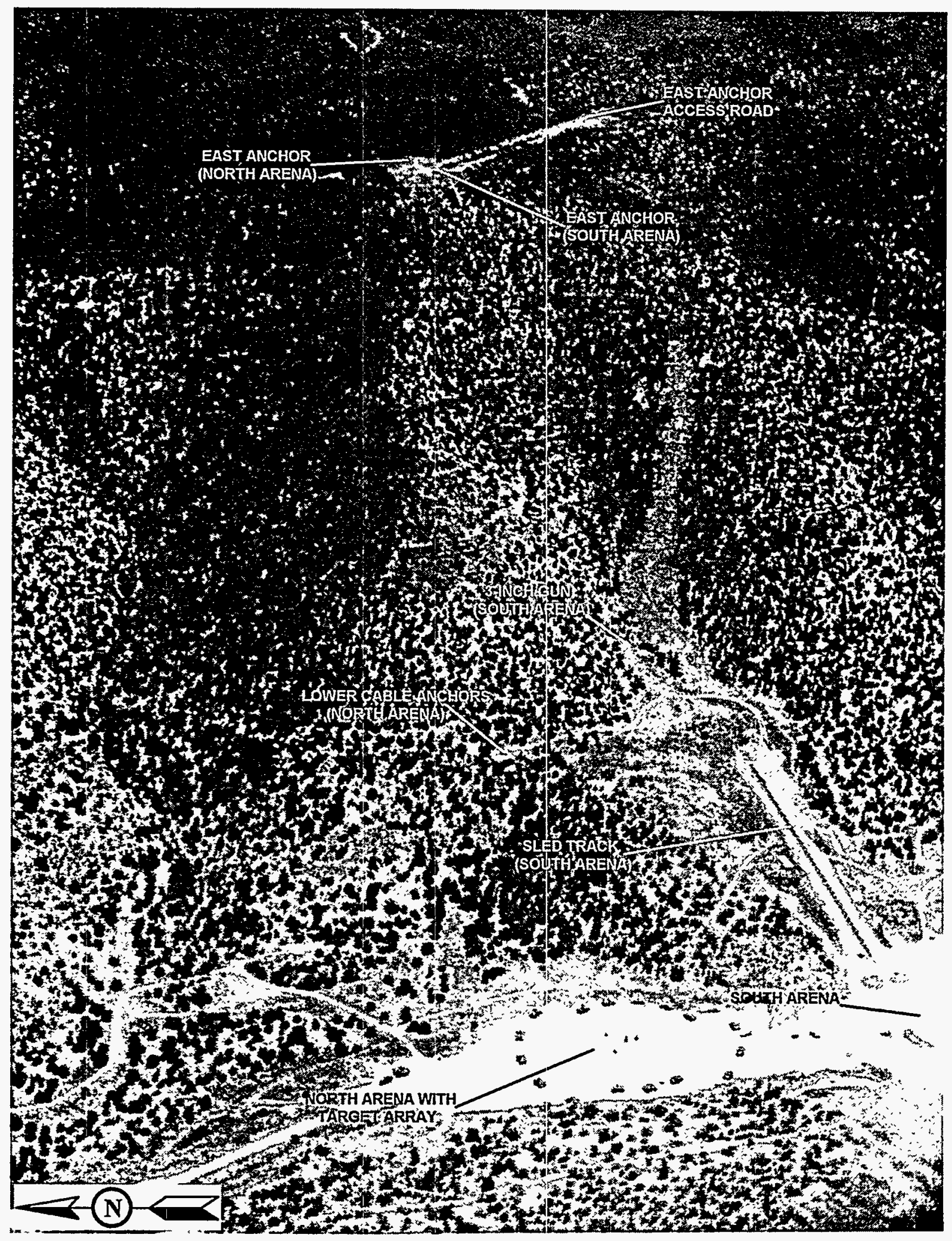

Figure 6. North Arena, SNL Aerial Cable Facility 
those used on aircraft carriers, or similar devices capable of attaining a soft impact. Heavier trolleys traveling at higher velocities may require retro-rockets to reduce the trolley kinetic energy to a level at which other restraining and braking mechanisms are effective.

\subsection{TEST FREQUENCY FOR ROCKETS AND EXPLOSIVES}

The ACF is used for an average of 220 tests per. year. Approximately 75 of these tests represent relatively environmentally benign activities such as testing operations involving passive electro-optical sensors or related activity. The remainder of these tests (approximately 145) involve detonation of high explosives or missile firings which inherently are environmentally intrusive. Tests in the latter category include the following:

\begin{tabular}{lc}
\hline \multicolumn{1}{c}{ Description } & $\begin{array}{c}\text { Assumed } \\
\text { Maximum Annual } \\
\text { Test Frequency }\end{array}$ \\
\hline Rocket-boosted pull-down tests (typically, 5 rockets per test) & 35 \\
Rocket-assisted aerial target/trolley tests (typically, 5 rockets per test) & 10 \\
Detonation of up to $2 \mathrm{~kg}$ of high explosives & 100 \\
Detonation of 50 to $450 \mathrm{~kg}$ of high explosives & $<1$ \\
Weapons firing (20-millimeter or 3-inch guns) up to 120 rounds of 3- & $<1$ \\
$\quad$ inch gun shots, or 100 rounds from 20-millimeter guns for each & \\
\hline
\end{tabular}

\subsection{VEHICLE USAGE}

During a typical year, ACF activity includes approximately 30,000 miles (mi) of vehicular movement, predominantly light vehicles used to transport SNL test personnel or test customers from the ACF offices in Technical Area III (TA-III) to the ACF. A small number of heavy construction support vehicles are used to transport test articles or used to prepare the ACF test areas for specialized testing. These vehicles include 
- Light vehicles (up to 1-ton truck); estimated daily usage is 6 vehicle round-trips along paved and unpaved roads from TA-III to Building 9931 and from Building 9931 to the test arenas. Annual frequency is 1,440 trips.

- Contractor/test customers light vehicles. Daily usage is slightly more than one roundtrip, and annual frequency is 240 trips.

- Heavy vehicles, including lowboys, cranes, and similar items, with an estimated annual frequency of 30 trips.

\subsection{PERSONNEL}

Approximately 15 SNL contractor employees are working at the facility on a regular basis. They report to the ACF project office in TA III some 13.1 kilometer $(\mathrm{km})(8.2 \mathrm{mi})$ away and drive to Building 9831 and the ACF during working hours. As many as 20 people, including transient test observers, may work at the facility during peak testing activity.

\subsection{UTILITIES}

Commercial electric power is available only at the Control Building (9831) and at the Winch Site. Only Buildings 9831 and 9832 (Explosives Assembly Building) are heated using propane heaters. Instrumentation and test control equipment items are electrically powered by portable motor generators brought to the site on an as-needed basis. The Instrumentation Bunker (Bldg. 9834) uses a 60 kilowatt $(\mathrm{kW})$ diesel-powered generator to provide electricity for heating, lighting, and instrumentation. The Explosives Assembly Building (Bldg. 9832) uses a $25 \mathrm{~kW}$ diesel-powered generator; however, a firm electrical power system is proposed to provide commercial power to this building. 


\subsection{DESCRIPTION OF THE PROPOSED ACTION}

This report is a technical background document for the Sol se Mete ACF Environmental Assessment (EA). The proposed action consists of continuation of the use of the facilities previously described in conducting test operations discussed in Section 1.0 above, as well as the following projects:

- Placement of temporary instrumentation, command, and control trailers.

- Facility maintenance of roads, cables, fire breaks, and post-test site clean up of common construction materials.

- Proposed facility upgrades include the following:

- Addition of restroom facilities next to Building 9831 that will incorporate a waste water capture tank;

- Addition of two explosive storage bunkers comprising approximately 56 square meters $\left(\mathrm{m}^{2}\right)$ [600 square feet $\left.\left(\mathrm{ft}^{2}\right)\right]$ installed next to Building 9832 within the fenced compound; and

— Extension of commercial electrical power to Building 9832.

- An increase from an average of five tests per year of articles containing depleted uranium to an average of fifteen tests per year.

The proposed additions will accommodate modernization and improvement of the $\mathrm{ACF}$ to support continued operations and new Department of Defense (DOD) test programs. The new construction would occupy approximately 0.5 hectare $(1.3$ acres $)$ of land, with new disturbance limited to less than 0.2 hectare $(0.5$ acres $)$.

\subsection{IMPACT IDENTIFICATION}

This report systematically examines the effects on air quality of the operation of the ACF. The examination is carried out in the context of the Federal, New Mexico, and Bernalillo County regulations pertaining to emission rates and concentrations of air contaminants, and 
the standards of the American Conference of Governmental Industrial Hygienists (ACGIH) pertaining to occupational safety and health $(\mathrm{ACGIH}, 1992)$.

Sources of air contaminants at the test site include vehicles (engines and fugitive dust), rocket motors, explosives, weapons firing using large bore guns (3-inch and 20-mm), electricity generators, and space heating. In order to develop an upper limit of test activity for which potential impacts are assessed, it is assumed, very conservatively, that 145 is the annual maximum number of tests that would involve use of rockets, explosives, or gun firings. These tests would be relatively more environmentally intrusive than drop tests, sensor evaluation tests, and most other types of tests. From a review of test summaries for the past six years, 145 tests was the maximum number for any year during that time period. During the past several years, the number of tests has decreased significantly. Accordingly, impacts resulting from actual (lower) testing rates should be significantly smaller than the impacts assessed in this report.

\subsection{AIR QUALITY STANDARDS}

The ACF is located in New Mexico Air Quality Control Region 6 and also within Bernalillo County. All air quality regions in New Mexico are identified by the extent to which they meet Ambient Air Quality Standards for five critical pollutants: total suspended particulates (TSP), carbon monoxide $(\mathrm{CO})$, nitrogen oxides $\left(\mathrm{NO}_{x}\right)$, sulfur oxides $\left(\mathrm{SO}_{x}\right)$, and ozone $\left(\mathrm{O}_{3}\right)$. Regulation of air quality within Bernalillo County has been delegated to the Albuquerque/Bernalillo County Air Quality Control Board (ABC/AQCB) by the state. The $A B C / A Q C B$ enforces both its own and state air quality regulations.

ABC/AQCB Ambient Air Quality Standards are listed in ABC/AQCB Standard No. 1, and New Mexico Ambient Air Quality Standards are set forth in Regulation Number 201 of the “Ambient Air Quality Standards and Air Quality Control Regulations" (NMED, 1994). Federal Ambient Air Quality Primary and Secondary Standards are provided by the National Ambient Air Quality Standards (NAAQS) as established by the EPA (Clean Air Act, 
42 U.S.C. 7470, et seq., as amended). Federal and State of New Mexico long-term Ambient Air Quality Standards are not to be exceeded, while Federal and State of New Mexico shortterm standards are not to be exceeded more than once a year.

The Federal and State of New Mexico ambient air quality standards are displayed in Table 1, and other New Mexico standards are in Tables 2 and 3. The ABC/AQCB standards are listed in Tables 4, 5, and 6. In most cases, $\mathrm{ABC} / \mathrm{AQCB}$ standards are equivalent to New Mexico standards.

According to New Mexico Environmental Improvement Board Air Quality Control Regulation 702, permits are required for new stationary air contaminant sources that emit more than $22,680 \mathrm{~kg}$ (25 tons) per year or $4.54 \mathrm{~kg}$ (10 lb) per hour of any regulated air contaminant for which there is a National or New Mexico Ambient Air Quality Standard. Because the SNL facility is not a new source, a permit is not required on the basis of this clause in regulation 702 , but the $22,680-\mathrm{kg}$ (25-ton) yearly emission rate is a useful guideline to help establish the relative importance of the air discharges of the ACF.

In nonattainment areas; special provisions of Regulation 702 require off-setting emission reduction of any contaminant whose ambient concentration would exceed Significant Ambient Concentrations. For the contaminants that would be emitted at the ACF, these levels and corresponding averaging times are presented in Table 6, which also has been adopted by the $\mathrm{ABC} / \mathrm{AQCB}$. The part of Bernalillo County that contains the SNL facilities is a nonattainment area only for carbon monoxide; however, the limits for the other contaminants also constitute a useful guideline, because there is the potential for Bernalillo County to become a noncompliance area.

New Mexico/Air Quality Control Regulation 702 (NM/AQCR) specifies the use of one-one hundredth of the 8-hour Occupational Exposure Limit (OEL) as the ambient level of toxic air pollutants to evaluate permit applications. For analysis purposes only, these levels for the materials that are expected to be released at the ACF are listed in Table 7. 
Table 1. Standards for Ambient Air Quality

\begin{tabular}{|c|c|c|c|}
\hline & $\begin{array}{c}\text { Federal } \\
\text { Primary Standard }\end{array}$ & $\begin{array}{c}\text { Federal } \\
\text { Secondary Standard }\end{array}$ & $\begin{array}{c}\text { New Mexico } \\
\text { Standard }\end{array}$ \\
\hline $\begin{array}{l}\text { Total suspended particulates (TSP) } \\
\text { 24-hour average } \\
\text { Annual mean }{ }^{d}\end{array}$ & $\begin{array}{c}150 \mu \mathrm{g} / \mathrm{m}^{3 a} \\
50 \mu \mathrm{g} / \mathrm{m}^{3}\end{array}$ & $\begin{array}{l}150 \mu \mathrm{g} / \mathrm{m}^{3} \\
50 \mu \mathrm{g} / \mathrm{m}^{3}\end{array}$ & $\begin{array}{l}150 \mu \mathrm{g} / \mathrm{m}^{3} \\
60 \mu \mathrm{g} / \mathrm{m}^{3}\end{array}$ \\
\hline $\begin{array}{l}\text { Sulfur dioxide } \\
\text { 24-hour average } \\
\text { Annual arithmetic mean } \\
\text { 3-hour average } \\
\text { 1-hour average }\end{array}$ & $\begin{array}{c}0.14 \mathrm{ppm}^{\mathrm{b}} \\
0.03 \mathrm{ppm}^{-} \\
-\end{array}$ & $\begin{array}{c}- \\
0.50 \mathrm{ppm} \\
-\end{array}$ & $\begin{array}{c}0.10 \mathrm{ppm} \\
0.02 \mathrm{ppm} \\
-\end{array}$ \\
\hline $\begin{array}{l}\text { Carbon monoxide } \\
\text { 8-hour average } \\
\text { 1-hour average }\end{array}$ & $\begin{array}{r}9.0 \mathrm{ppm} \\
35.0 \mathrm{ppm}\end{array}$ & $\begin{array}{r}9.0 \mathrm{ppm} \\
35.0 \mathrm{ppm}\end{array}$ & $\begin{array}{r}8.7 \mathrm{ppm} \\
13.1 \mathrm{ppm}\end{array}$ \\
\hline Ozone (1-hour average) ${ }^{c}$ & $0.12 \mathrm{ppm}$ & $0.12 \mathrm{ppm}$ & $0.06 \mathrm{ppm}$ \\
\hline $\begin{array}{l}\text { Nitrogen dioxide } \\
\text { 24-hour average } \\
\text { Annual arithmetic mean } \\
\text { 1-hour average }\end{array}$ & $100 \underline{\mu \mathrm{g} / \mathrm{m}^{3}}$ & $100 \underline{\mu \mathrm{g} / \mathrm{m}^{3}}$ & $\begin{array}{l}0.10 \mathrm{ppm} \\
0.05 \mathrm{ppm} \\
-\end{array}$ \\
\hline
\end{tabular}

a $\mu \mathrm{g} / \mathrm{m}^{3}$-micrograms per cubic meter

b ppm-parts per million by volume

c For New Mexico, the term "photochemical oxidants" is used rather than "ozone"

d The Federal standard specifies arithmetic mean; the New Mexico standard specifies geometric mean. 
Table 2. New Mexico Standards for Significant Emission Rates

\begin{tabular}{|c|c|}
\hline Pollutant & $\begin{array}{c}\text { Emissions Rate } \\
\text { (tons/year) }\end{array}$ \\
\hline Carbon monoxide & 100 \\
\hline Nitrogen oxides & 40 \\
\hline Sulfur dioxide & 40 \\
\hline Particulate matter & 25 \\
\hline Ozone $(\mathrm{NMHC})^{\mathrm{a}}$ & 40. (NMHC) \\
\hline Lead & 0.6 \\
\hline Asbestos & 0.007 \\
\hline Beryllium & 0.0004 \\
\hline Mercury & 0.1 \\
\hline Vinyl chloride & 1 \\
\hline Fluorides & 3 \\
\hline Sulfuric acid mist & 7 \\
\hline Hydrogen sulfide $\left(\mathrm{H}_{2} \mathrm{~S}\right)$ & 10 \\
\hline Total reduced sulfur (including $\mathrm{H}_{2} \mathrm{~S}$ ) & 10 \\
\hline Any other pollutant regulated under the Clear Air Act & Any emission rate \\
\hline Each regulated pollutant & $\begin{array}{l}\text { Emission rate or net emissions } \\
\text { increase that causes an air } \\
\text { quality impact of } 1 \mu \mathrm{g} / \mathrm{m}^{3} \text { or } \\
\text { greater (24-hour basis) in any } \\
\text { Class I area located within } \\
100 \mathrm{~km} \text { of the source }\end{array}$ \\
\hline
\end{tabular}

a nonmethane hydrocarbons

Data Source: New Mexico Air Quality Control Regulation 707 (1990) 
Table 3. New Mexico Standards for Significant Monitoring Concentrations

\begin{tabular}{|lcc|}
\hline \multicolumn{1}{|c|}{ Pollutant } & $\begin{array}{c}\text { Air Quality } \\
\text { Concentration } \\
\left(\mu \mathrm{g} / \mathrm{m}^{3}\right)\end{array}$ & Averaging Time \\
\hline Carbon monoxide & 575 & 8 hours \\
Nitrogen dioxide & 14 & 1 year \\
Sulfur dioxide & 13 & 24 hours \\
Total Suspended Particulates & 10 & 24 hours \\
Ozone (NMHC) & $-\mathrm{a}-$ & \\
Lead & 0.1 & 3 months \\
Asbestos & $-\mathrm{b}-$ & \\
Beryllium & 0.0005 & 24 hours \\
Mercury & 0.25 & 24 hours \\
Vinyl chloride & 15 & 24 hours \\
Fluorides & 0.25 & 24 hours \\
Sulfuric acid mist & $-\mathrm{b}-$ & \\
Total reduced sulfur (including $\left.\mathrm{H}_{2} \mathrm{~S}\right)$ & $-\mathrm{c}-$ & \\
Reduces sulfur (including $\left.\mathrm{H}_{2} \mathrm{~S}\right)$ & $-\mathrm{c}-$ & 1 hour \\
Hydrogen sulfide & 0.20 & \\
\hline
\end{tabular}

a No specific air quality concentration for ozone is prescribed. Exemptions are granted when a source's nonmethane hydrocarbons (NMHC) emissions are less than 100 tons/year.

b No acceptable monitoring techniques available at this time. Therefore, monitoring is not required until acceptable techniques are available.

c No acceptable monitoring techniques available at this time. However, techniques are expected to be available soon.

Data Source: New Mexico Air Quality Control Regulation 707 (1990) 
Table 4. Significant Emission Rates for ABC/AQCB

\begin{tabular}{|c|c|}
\hline Pollutant & $\begin{array}{c}\text { Emissions Rate } \\
\text { (tons/year) }\end{array}$ \\
\hline Carbon monoxide & 100 \\
\hline Nitrogen dioxides & 40 \\
\hline Sulfur dioxide & 40 \\
\hline \multicolumn{2}{|l|}{ Particulate matter } \\
\hline Particulate matter emissions & 25 \\
\hline $\mathrm{PM}_{10}$ emissions & 15 \\
\hline Ozone $(\mathrm{VOC})^{\mathrm{a}}$ & 40. $(\mathrm{VOC})^{\mathrm{a}}$ \\
\hline Lead & 0.6 \\
\hline Asbestos & 0.007 \\
\hline Beryllium & 0.0004 \\
\hline Mercury & 0.1 \\
\hline Vinyl chloride & 1 \\
\hline Fluorides & 3 \\
\hline Sulfuric acid mist & 7 \\
\hline Hydrogen sulfide $\left(\mathrm{H}_{2} \mathrm{~S}\right)$ & 10 \\
\hline Total reduced sulfur (including $\mathrm{H}_{2} \mathrm{~S}$ ) & 10 \\
\hline Reduced sulfur (including $\mathrm{H}_{2} \mathrm{~S}$ ) & 10 \\
\hline Any other regulated pollutant & Any emission rate \\
\hline Each regulated pollutant & $\begin{array}{l}\text { Emission rate or net emissions increase } \\
\text { associated with a major stationary source or } \\
\text { a major modification that causes an air } \\
\text { quality impact of } 1 \mu \mathrm{g} / \mathrm{m}^{3} \text { or greater (24- } \\
\text { hour average) in any Class I area located } \\
\text { within } 10 \mathrm{~km} \text { of the source }\end{array}$ \\
\hline
\end{tabular}

a Volatile Organic Compounds

Data Source: ABC/AQCB (1990), pp. 29-33 
Table 5. Significant Monitoring Standards for ABC/AQCB

\begin{tabular}{|lcc|}
\hline \multicolumn{1}{|c|}{ Pollutant } & $\begin{array}{c}\text { Air Quality } \\
\text { Concentration } \\
\left(\mu \mathrm{g} / \mathrm{m}^{3}\right)\end{array}$ & Averaging Time \\
\hline Carbon monoxide & 575 & 8 hours \\
Nitrogen dioxides & 14 & 1 year \\
Sulfur dioxide & 13 & 24 hours \\
Particulate matter & 10 & 24 hours \\
$\quad$ PSP & 10 & 24 hours \\
PM & & \\
Ozone & $-\mathrm{a}-$ & 3 months \\
Lead & 0.1 & \\
Asbestos & $-\mathrm{b}-$ & 24 hours \\
Beryllium & 0.001 & 24 hours \\
Mercury & 0.25 & 24 hours \\
Vinyl chloride & 5 & 24 hours \\
Fluorides & 0.25 & 1 hour \\
Sulfuric acid mist & $-\mathrm{b}-$ & 1 hour \\
Total reduced sulfur (including $\left.\mathrm{H}_{2} \mathrm{~S}\right)$ & 10 & 1 hour \\
Reduced sulfur (including $\left.\mathrm{H}_{2} \mathrm{~S}\right)$ & 10 & \\
Hydrogen sulfide $\left(\mathrm{H}_{2} \mathrm{~S}\right)$ & 0.20 & \\
\hline
\end{tabular}

a No specific air quality concentration for ozone is prescribed. Exemptions are granted when a source's volatile organic compounds (VOC) emissions are less than 100 tons/year.

b No acceptable monitoring techniques available at this time. Therefore, monitoring is not required until acceptable techniques are available.

Data Source: ABC/AQCB (1990) 
Table 6. Significant Ambient Standards for ABC/AQCB

\begin{tabular}{|lccccc|}
\hline & \multicolumn{5}{c|}{ Averaging Time } \\
\cline { 2 - 6 } \multicolumn{1}{c}{ Pollutant } & 1 Year & 24 Hours & 8 Hours & 3 Hours & 1 Hours \\
\hline Sulfur dioxide & $1.0 \mu \mathrm{g} / \mathrm{m}^{3}$ & $5 \mu \mathrm{g} / \mathrm{m}^{3}$ & - & $25 \mu \mathrm{g} / \mathrm{m}^{3}$ & - \\
$\mathrm{PM}_{10}$ & $1.0 \mu \mathrm{g} / \mathrm{m}^{3}$ & $5 \mu \mathrm{g} / \mathrm{m}^{3}$ & - & - & - \\
Nitrogen dioxide & $1.0 \mu \mathrm{g} / \mathrm{m}^{3}$ & - & - & - & - \\
Carbon monoxide & - & - & $0.5 \mathrm{mg} / \mathrm{m}^{3}$ & - & $2 \mathrm{mg} / \mathrm{m}^{3}$ \\
\hline
\end{tabular}

Data Source: ABC/AQCB (1989)

Table 7. Occupational Exposure Limits (OEL) Reduced by a Factor of 100 for Additional Substances at ACF

\begin{tabular}{|lc|}
\hline \multicolumn{1}{|c|}{ Substance } & $\begin{array}{c}\text { OEL } \\
\text { (reduced) }\end{array}$ \\
\hline Hydrogen chloride & $70.0 \mu \mathrm{g} / \mathrm{m}^{3}$ \\
Aluminum oxide & $100.0 \mu \mathrm{g} / \mathrm{m}^{3}$ \\
Magnesium oxide & $100.0 \mu \mathrm{g} / \mathrm{m}^{3}$ \\
Potassium hydroxide & $20.0 \mu \mathrm{g} / \mathrm{m}^{3}$ \\
Hydrogen cyanide & $100.0 \mu \mathrm{g} / \mathrm{m}^{3}$ \\
Ammonia & $180.0 \mu \mathrm{g} / \mathrm{m}^{3}$ \\
Methane & $-\mathrm{a}-$ \\
Hydrocarbons & $-\mathrm{a}-$ \\
\hline
\end{tabular}

a Simple asphyxiant. Oxygen content of air must not be reduced below 18 percent.

Data Source: New Mexico Air Quality Control Regulation 702 (1990) and American Conference of Governmental Industrial Hygienists (1992) 
This page intentionally left blank. 


\subsection{AIR QUALITY BASELINE}

Very little air quality baseline information is available for the ACF. SNL conducts extensive radiological and water monitoring programs; however, with the exception of certain hazardous emissions, levels of common air contaminants are not monitored. SNL plans to increase its monitoring of air quality and meteorology during calendar year 1994, but data sufficient to establish an air quality baseline were not available at this writing.

The ACF is located in Bernalillo County, and Bernalillo County is a noncompliance area for carbon monoxide. The ABC/AQCB conducts routine monitoring at several sites throughout the area, but none are close enough to the ACF to provide a meaningful characterization of the atmosphere at the site. Figure 7 is a map showing the locations of environmental monitoring locations for radioactive surveillance in Technical Areas I through V and KAFB. Table 8 is a description of the locations and sampling types employed. Although radiological monitoring does not provide baseline data for air quality, this information helps to establish the scope of the SNL environmental monitoring program.

Most of the carbon monoxide in Bernalillo County originates within the City of Albuquerque, but the prevailing winds do not carry pollutants toward the ACF site in high concentrations. Much of the time, it is likely that the conditions at the ACF are more similar to those in the surrounding semi-rural areas of the county rather than to those in Albuquerque. Because of the large tracts of sparsely vegetated land to the west of the test site, the particulate content undoubtedly increases during periods of strong westerly winds. 


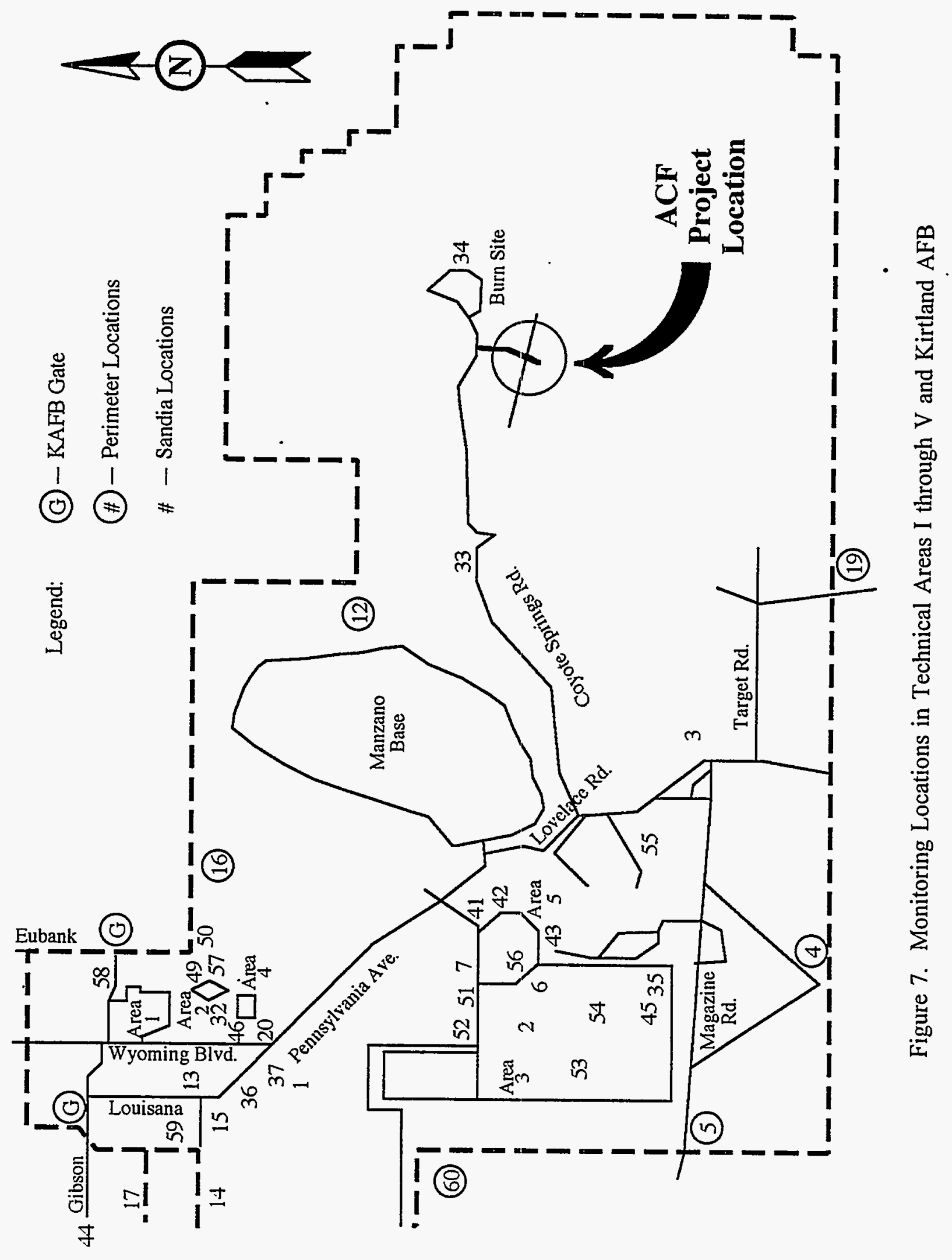


Table 8. SNL, Albuquerque, Environmental Monitoring Locations and Sample Types for Radioactive Surveillance

\begin{tabular}{|c|c|c|c|}
\hline $\begin{array}{l}\text { Location } \\
\text { Number }\end{array}$ & Location & $\begin{array}{c}\text { Sample } \\
\text { Description }^{\mathrm{a}}\end{array}$ & Type $^{b}$ \\
\hline 1 & Pennsylvania Avenue & $S$ & $\mathrm{~V}, \mathrm{~S}, \mathrm{~T}$ \\
\hline $2 \mathrm{NW}$ & Radioactive Waste Disposal Site NW & $\mathrm{S}$ & $\mathrm{V}, \mathrm{S}, \mathrm{T}$ \\
\hline $2 \mathrm{NE}$ & Radioactive Waste Disposal Site NE & $S$ & $\mathrm{~V}, \mathrm{~S}$ \\
\hline $2 \mathrm{SE}$ & Radioactive Waste Disposal Site SE & $\mathrm{S}$ & $\mathrm{V}, \mathrm{S}$ \\
\hline $2 \mathrm{SW}$ & Radioactive Waste Disposal Site SW & $\mathrm{S}$ & $\mathrm{V}, \mathrm{S}$ \\
\hline 3 & Coyote Canyon Control & $S$ & $\mathrm{~V}, \mathrm{~S}, \mathrm{~T}$ \\
\hline 4 & Isleta Reservation Gate & $P$ & $\mathrm{~V}, \mathrm{~S}, \mathrm{~T}$ \\
\hline $5^{\mathfrak{c}}$ & McCormick Gate & $\mathbf{P}$ & $\mathrm{V}, \mathrm{S}, \mathrm{T}$ \\
\hline $6^{c}$ & East of Technical Area III, Water Tower & $S$ & $\mathrm{~V}, \mathrm{~S}, \mathrm{~T}$ \\
\hline $7^{\mathfrak{c}}$ & North of Technical Area V, Arroyo & $\mathrm{S}$ & $\mathrm{V}, \mathrm{S}, \mathrm{T}$ \\
\hline 8 & Corrales Bridge & $\mathrm{C}$ & $\mathrm{V}, \mathrm{S}, \mathrm{W}$ \\
\hline 9 & Sedillo Hill I-40, East of Albuquerque & $\mathrm{C}$ & $\mathrm{V}, \mathrm{S}$ \\
\hline 10 & Oak Flats & $\mathrm{C}$ & $\mathrm{V}, \mathrm{S}, \mathrm{T}$ \\
\hline 11 & Isleta Pueblo, Rio Grande & $\mathrm{C}$ & $\mathrm{V}, \mathrm{S}, \mathrm{T}, \mathrm{W}$ \\
\hline 12 & NE perimeter & $\mathrm{P}$ & $\mathrm{V}, \mathrm{S}$ \\
\hline 13 & Base Well 1 & $S$ & $W$ \\
\hline 14 & Base Well 2 (not running) & S & W \\
\hline 15 & Base Well 7 & $S$ & W \\
\hline $16^{\mathrm{c}}$ & Four Hills & $\mathrm{P}$ & $\mathrm{V}, \mathrm{S}, \mathrm{T}$ \\
\hline 17 & Base Well 14 & S & W \\
\hline 18 & North Perimeter Road & $\mathrm{P}$ & $\mathrm{T}$ \\
\hline 19 & Seismic Center Gate & $\mathrm{P}$ & $\mathrm{V}, \mathrm{S}, \mathrm{T}$ \\
\hline 20 & Technical Area IV, SW & S & $\mathrm{V}, \mathrm{S}, \mathrm{T}$ \\
\hline 21 & Bernalillo Fire Station 10, Tijeras & $\mathrm{C}$ & $\mathrm{T}$ \\
\hline 22 & Los Lunas Fire Station & $\mathrm{C}$ & $\mathrm{T}$ \\
\hline 23 & Rio Rancho Fire Station, 19th Avenue & $\mathrm{C}$ & $\mathrm{T}$ \\
\hline 24 & Corrales Fire Station & $\mathrm{C}$ & $\mathrm{T}$ \\
\hline 25 & Placitas Fire Station & $\mathrm{C}$ & $\mathrm{V}, \mathrm{S}, \mathrm{T}$ \\
\hline 26 & $\mathrm{ABQ}^{\mathrm{d}}$ Fire Station 9, Menaul NE & $\mathrm{C}$ & $\mathrm{T}$ \\
\hline 27 & ABQ Fire Station 11 , Southern SE & $\mathrm{C}$ & $\mathrm{T}$ \\
\hline 28 & ABQ Fire Station 2, High SE & $\mathrm{C}$ & $T$ \\
\hline 29 & ABQ Fire Station 7,47 th NW & $\mathrm{C}$ & $\mathrm{T}$ \\
\hline 30 & ABQ Fire Station 6, Griegos NW & $\mathrm{C}$ & $\mathrm{T}$ \\
\hline 31 & Technical Area II, Guard Gate & $S$ & $\mathrm{~T}$ \\
\hline $32^{c}$ & Technical Area II, Building 935 & $S$ & S \\
\hline $33^{c}$ & Coyote Spring & $\mathrm{S}$ & $\mathrm{V}, \mathrm{S}, \mathrm{W}$ \\
\hline 34 & Lurance Canyon & $\mathrm{S}$ & $\mathrm{V}, \mathrm{S}$ \\
\hline 35 & Chemical Waste Disposal Site & $S$ & V,S \\
\hline 36 & Base Well 4 (not running) & $\mathrm{S}$ & W \\
\hline 37 & Base Well 8 (not running) & $S$ & W \\
\hline 38 & Base Well Lift Station to Manzano (not running) & S & W \\
\hline 39 & NW DOE Complex & $\mathrm{P}$ & $\mathrm{T}$ \\
\hline
\end{tabular}


Table 8. SNL, Albuquerque, Environmental Monitoring Locations and Sample Types for Radioactive Surveillance (concluded)

\begin{tabular}{|l|l|c|c|}
\hline \multicolumn{1}{|c|}{$\begin{array}{c}\text { Location } \\
\text { Number }\end{array}$} & & $\begin{array}{c}\text { Sample } \\
\text { Description }^{\mathbf{a}}\end{array}$ & Type $^{\mathbf{b}}$ \\
\hline 40 & Technical Area I, NE by Building 852 & $\mathrm{P}$ & $\mathrm{T}$ \\
41 & Technical Area V, NE Fence & $\mathrm{S}$ & $\mathrm{V}, \mathrm{S}, \mathrm{T}$ \\
42 & Technical Area V, E Fence & $\mathrm{S}$ & $\mathrm{V}, \mathrm{S}, \mathrm{T}$ \\
43 & Technical Area V, SE Fence & $\mathrm{S}$ & $\mathrm{V}, \mathrm{S}, \mathrm{T}$ \\
44 & Base Well 12 & $\mathrm{S}$ & $\mathrm{W}$ \\
45 & Technical Area III, RMWMF Site, NW Corner & $\mathrm{S}$ & $\mathrm{V}, \mathrm{S}, \mathrm{T}$ \\
46 & Technical Area II, South Corner & $\mathrm{S}$ & $\mathrm{T}$ \\
47 & Tijeras Canyon East of AIV & $\mathrm{S}$ & $\mathrm{T}$ \\
48 & Tijeras Canyon Northeast of AIV & $\mathrm{S}$ & $\mathrm{T}$ \\
49 & Near the proposed ECF Site & $\mathrm{S}$ & $\mathrm{V}, \mathrm{S}$ \\
50 & Base Well 11 & $\mathrm{S}$ & $\mathrm{W}$ \\
51 & Ditch, technical Area V, N & $\mathrm{S}$ & $\mathrm{V}, \mathrm{S}$ \\
52 & Technical Area III, NE/6563 & $\mathrm{S}$ & $\mathrm{V}, \mathrm{S}$ \\
53 & Track, Technical Area III, S & $\mathrm{S}$ & $\mathrm{V}, \mathrm{S}$ \\
54 & Technical Area III, 6630 & $\mathrm{S}$ & $\mathrm{V}, \mathrm{S}$ \\
55 & Technical Area III, 9939 & $\mathrm{S}$ & $\mathrm{V}, \mathrm{S}$ \\
56 & Technical Area V, W/6488 & $\mathrm{S}$ & $\mathrm{V}, \mathrm{S}$ \\
57 & Technical Area III, S & $\mathrm{S}$ & $\mathrm{V}, \mathrm{S}$ \\
58 & N Base Housing & $\mathrm{P}$ & $\mathrm{V}, \mathrm{S}$ \\
59 & Zia Park/SE & $\mathrm{P}$ & $\mathrm{V}, \mathrm{S}$ \\
$60^{\mathrm{c}}$ & Tijeras Arroyo & $\mathrm{P}$ & $\mathrm{V}, \mathrm{S}$ \\
61 & Airport (west end) & $\mathrm{P}$ & $\mathrm{V}, \mathrm{S}$ \\
62 & East Resident & $\mathrm{C}$ & $\mathrm{V}, \mathrm{S}$ \\
\hline
\end{tabular}

a $\mathrm{S}=\mathrm{SNL}$, Albuquerque; $\mathrm{P}=$ perimeter of $\mathrm{SNL}$, Albuquerque; and $\mathrm{C}=$ community

b V=vegetation, $S=$ soil, $W=$ water, and $T=T L D$ (thermoluminescent dosimeters)

c Triplicate sampling sites:

$5,6,7,16$, and 60 for $\mathrm{V}$ and $\mathrm{S}$

32 for S only

33 for $W$ only

d $\mathrm{ABQ}=\mathrm{Albuquerque}$

Data Source: SNL (1990) 


\subsection{ENVIRONMENTAL CONSEQUENCES}

Several devices and mechanisms used at the ACF can produce atmospheric contaminants. Some of those which produce gaseous contaminants are:

- Rocket motors used to accelerate test apparatus either along the trolley or downward with the rocket sied track pull-down mechanism;

- Chemical explosive devices undergoing test;

- Engines of vehicles and electricity generators; and

- Space heating equipment.

Most gaseous contaminants are nonreactive and remain entrained in the air flow after release. Reactive materials which may be produced by some activities gradually decrease in concentration by reacting with atmospheric constituents or with the ground. For the purposes of the air quality modeling performed here, it is assumed that none of the contaminants are removed from the effluent plume by chemical reactions.

In addition to gaseous contaminants, several devices and mechanisms can produce particulate contaminants. These include:

- Certain rocket motors;

- Chemical explosives, particularly soil ejected into the air;

- Vehicle and electricity generator engines;

- Vehicular traffic on unimproved roads (fugitive dust);

- Wind interaction with unimproved roads and other disturbed land areas; and

- Construction and facilities maintenance activities.

Some mechanisms produce both types of contaminants. Particles may settle out of the effluent plume; however, as in the case of chemical removal processes, this effect is ignored. 
It was assumed that construction and facilities maintenance would be low-intensity activities whose major effect on particulate emissions would be from the additional vehicular traffic generated. If several small construction and maintenance projects were undertaken simultaneously, it would be necessary to assess their cumulative effects.

Air quality regulations established by Federal, New Mexico, and Bernalillo County agencies have been considered. Both the total annual quantities of the contaminants released and their concentrations in the air averaged over specified time periods must be considered under these regulations.

\subsection{METHODOLOGY}

In most cases, the absolute quantity of an air contaminant that is released by an activity associated with the test site can be estimated with reasonable accuracy using straightforward methods. For example, the EPA maintains tables of emission factors that relate air contaminant emissions from motor vehicles to vehicle miles traveled, and also has developed empirical formulae that can be used to estimate fugitive dust production by vehicles related directly to vehicle miles traveled and to road conditions. Air contaminants released by booster rockets have been tabulated for each of the booster types that may be used at the ACF. Concentrations of the atmospheric contaminants are more complex to estimate. The preferred method is to model the flow of the contaminants from the source by using an atmospheric dispersion model. Many different dispersion models have been developed for specialized applications. Some are more applicable to specific situations than others. For the present work, two different models were used. One of these, INPUFF, (Peterson, 1986) is a general purpose model that was used for all of the modeling except for those contaminants directly related to vehicular traffic on the roads. For modeling the contaminants produced by vehicular traffic, a specialized model called HIWAY2 (EPA, 1980) was used. 


\subsubsection{The INPUFF Model}

The INPUFF model was developed at the Atmospheric Research and Exposure Assessment Laboratory of the U.S. Environmental Protection Agency (EPA), Research Triangle Park, North Carolina (Peterson, 1986). The model has been implemented on a variety of computer platforms. The MS-DOS desktop computer version was used for the present work. The program was developed in FORTRAN-77, and the EPA makes both the executable and the program source files available to facilitate maintenance and customization. The unmodified program was used for the present work.

INPUFF can be applied to a variety of release scenarios including industrial stacks and accidental spills. It is well-suited for application to the ACF, because it allows the operator to model both sustained and brief release events, and to specify the horizontal wind field in great detail. INPUFF does not explicitly take terrain effects into account, but the modeler can include terrain effects through appropriate modifications of the wind field. INPUFF also can include the effects of deposition of material from the plume, although this option was not used for the present work.

The required input data for the INPUFF model include the following:

- The release parameters as functions of time for the contaminant material, including release rate, temperature, and release height;

- The release velocity and air flow rate, if applicable;

- The motion parameters of the source;

- The Pasquill atmospheric stability category and mixing height;

- The positions of the receptors, i.e., the positions at which predicted concentrations are desired;

- The wind speed and direction as functions of time, and if not uniform, the detailed wind field data supplied as a tabular listing of the horizontal wind components at defined measurement points; 
- The vertical and horizontal wind direction standard deviations (used only with one of the three available dispersion algorithms);

- Settling and deposition parameters for the contaminant, if applicable; and

- The desired time iteration parameters.

The model package also includes a menu-driven program that facilitates preparation of the input data file.

\subsubsection{The HIWAY2 Model}

Modeling of the vehicle-produced gaseous and particulate air contaminants in the vicinity of the ACF was performed using a computer model called HIWAY2. Like INPUFF, HIWAY2 was developed by the Atmospheric Research and Exposure Assessment Laboratory of the U.S. Environmental Protection Agency (EPA), Research Triangle Park, North Carolina (EPA, 1980). HIWAY2 was optimized for the case of a steady linear source of contaminant material, specifically, vehicular traffic on roads. The traffic flow associated with the activities at the $\mathrm{ACF}$ is rather light; however, because the averaging times that are required to demonstrate regulatory compliance are one hour and longer, it is reasonable to treat the release as steady and continuous. Likewise, the roads at the ACF site are not straight. The model can be successfully applied to segments of the roads that can be approximated as straight segments. This point will be discussed in greater detail in Section 4.1.3. For computer simulations, fugitive dust generated by wind effects on the roads was included with the vehicle-produced dust for modeling.

The input data required by HIWAY2 include the following:

- The emission rate of the material in grams per meter of road per second;

- The end points of the road segment in a coordinate system in which the $\mathrm{x}$-axis is in the east-west direction (east positive) and the y-axis is in the north-south direction (north positive); 
- The direction and speed of the wind;

- An estimate of the Pasquill stability in a simplified three-category scheme (stable, neutral, or unstable); and

- The height of the mixing layer.

For the low emission rates restricted to the work day that will occur as a result of the ACF activity, neither the stability category nor the mixing height significantly affect the concentrations of the contaminants near the test area.

\subsubsection{Other Considerations}

A major complication to the atmospheric dispersion modeling at the ACF is that the facilities are located in a narrow canyon. Even the main access road is largely confined to canyon and arroyo areas. The terrain of the canyon bottom can have major effects on the dispersion of the effluent plume produced by most of the activities. An entrained plume can be carried along the canyon bottom by the wind; when the wind encounters a terrain feature such as a canyon wall, it deflects laterally and/or vertically with the moving air or is deposited by a kinetic process. As already stated, deposition and settling effects were neglected. Neglecting these effects results in more conservative concentration estimates for gases, and the concentration estimates for particulates are more conservative for large transport distances.

The major shortcoming of INPUFF with regard to terrain effects is that the wind field specification does not allow for vertical components. However, this fact does not significantly reduce the usefulness of the program for the types of predictions required for the purposes of this document. Concentrations resulting from using a purely horizontal wind field represent a conservative case in terms of personnel exposure compared to a case using a wind field with upward components that better approximates the vertical dispersion.

HIWAY2 provides a mechanism for considering a road in a cut; however, when that option is used, the predicted concentrations apply only to areas outside the cut. There is no other 
mechanism available to include terrain in HIWAY2. The present analysis using this model indicates that the concentration of fugitive dust would drop below levels of regulatory

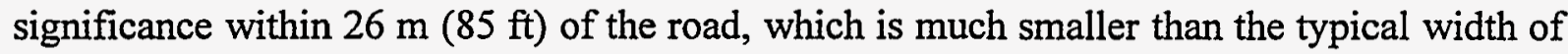
the canyon bottom. None of the other vehicle-produced contaminants would ever reach regulatory levels even at the road edge. Therefore, here too, the lack of ability to deal with complex terrain is of little practical consequence.

Many of the air contaminant-producing activities associated with the ACF are essentially continuous through the work day or throughout a 24-hour day. Among these are space heating and electricity generator usage. Vehicle usage is not continuous, but it is sufficiently uniform, and the contaminants are sufficiently dispersed, that the assumption of continuity does not degrade the predictions for 1 -hour and longer time periods. Some of the activities can be thought of as point events in time and/or space. Detonation of a test explosive device falls into this category. Booster rockets typically burn for only a few seconds, and on the time scale necessary for dispersion modeling, they can still be thought of as point events in time. However, rocket-boosted equipment can travel large distances during the burn time and that movement must be taken into account.

Maximum contaminant release scenarios were used to compute total emission of air contaminants. For estimating the effects of booster rockets, the booster that produces the largest quantity of a given contaminant was used as the basis for the calculations for that contaminant. For example, this means that the calculations for lead are based on a different booster configuration than the calculations for carbon monoxide. Booster rocket information, such as exhaust quantity and composition and maximum numbers used per mission, was provided by SNL. All booster motor burn times are short with respect to required averaging periods and appropriate model iteration times, and so need not be known with great precision.

In all cases, it was assumed that the average speed of a boosted trolley during the rocket burn was $50 \mathrm{~m} / \mathrm{s}(164 \mathrm{fps})$. 


\subsection{SOURCES AND MODELING}

Each of the separately identified sources of air contaminants will be discussed in greater detail. In most cases, it is appropriate to handle both gaseous and particulate contaminants that result from the same release mechanism in the same treatment.

\subsubsection{Booster Rocket Motors}

Tables 9 and 10 summarize the information about the booster rockets that may be used at the ACF. Table 9 includes the information on the mass of the propellant, the maximum number of units that could be used in any single operation, and the total mass of the exhaust products. Table 10 presents the exhaust composition for these boosters. By using the information in the two tables, a straightforward computation gives the quantity of each of the air contaminants that would be released by a single booster of each type. This information is included in Table 11. At the ACF, only Zuni and HVAR rocket motors are used. The information on the other

boosters is included in the tables to help establish the scale of the contaminants released by the Zuni and HVAR boosters.

The primary exhaust components of both the Zuni and HVAR boosters are carbon dioxide, carbon monoxide, water vapor, hydrogen, and nitrogen. The HVAR also produces small amounts of sulfur dioxide, potassium oxide, and lead compounds. Of these, carbon monoxide, lead, and sulfur dioxide are regulated air contaminants. When exposed to water vapor in the air, potassium oxide $\left(\mathrm{K}_{2} \mathrm{O}\right)$ rapidly reacts to form potassium hydroxide $(\mathrm{KOH})$, and this material is considered a toxic air pollutant by NM/AQCR 702. Even in the driest month (June), the average daytime relative humidity in the Albuquerque area is greater than 20 percent which corresponds to an absolute water vapor content of about 3.5 gram per cubic meter $\left(\mathrm{g} / \mathrm{m}^{3}\right)$ at the average daytime temperature. At this level, the volume of air with which the rocket exhaust mixes contains more than 100 times the minimum amount of water vapor required for the complete conversion of $\mathrm{K}_{2} \mathrm{O}$ to $\mathrm{KOH}$. Therefore, the data in Table 11 have been adjusted to account for the complete conversion of $\mathrm{K}_{2} \mathrm{O}$ to $\mathrm{KOH}$. For some boosters in 
Table 9, the composition of the propellant indicates that materials not included in Table 10 should be expected in the exhaust. In those cases, the data in Table 11 have been adjusted accordingly. For example, the propellant used in the Nike booster contains 1.9 percent lead stearate, so each booster would emit $1.7 \mathrm{~kg}(3.74 \mathrm{lb})$ of elemental lead. Aluminum oxide, hydrogen chloride, magnesium oxide, and copper oxide which are produced by some boosters also are considered toxic air pollutants by NM/AQCR 702, but because they are not produced by Zuni or HVAR boosters, they are not considered further. Federal Regulations contained in $40 \mathrm{CFR} 302.6$ require that lead releases in excess of $4.54 \mathrm{~kg}(10 \mathrm{lb})$ be reported by telephone to the National Response Center (800-424-8802). From Table 12, the maximum release of lead from booster rockets at the ACF would be $0.2 \mathrm{~kg}(0.44 \mathrm{lb})$; therefore, no reporting requirement is associated with their use.

Table 9. Rocket Exhaust Quantities

\begin{tabular}{|lccc|}
\hline \multicolumn{1}{|c}{ Rocket Motor } & $\begin{array}{c}\text { Propellant Mass } \\
(\mathrm{kg})\end{array}$ & $\begin{array}{c}\text { Maximum } \\
\text { Number Used per } \\
\text { Test Event }\end{array}$ & $\begin{array}{c}\text { Maximum Exhaust } \\
\text { Products (kg) per } \\
\text { Test Event }\end{array}$ \\
\hline Nike & 341 & 3 & 1,023 \\
Zuni & 15.2 & 25 & 380 \\
Honest John & 931 & 4 & 3,724 \\
Improved Honest John & 756 & 4 & 3,024 \\
Javelin & 109 & 3 & 327 \\
Little John & 110 & 6 & 660 \\
Mighty Mouse & 2.7 & 25 & 68 \\
Recruit & 120 & 3 & 360 \\
Terrier Booster & 546 & 1 & 546 \\
Terrier Sustainer & 152 & 7 & 1,064 \\
HVAR & 10.9 & 25 & 272 \\
Hawk & 45 & 5 & 225 \\
\hline
\end{tabular}

Data Source: ACTC Final EIS (DA, 1991) 
Table 10. Rocket Exhaust Gas Composition

\begin{tabular}{|c|c|c|c|c|c|c|c|c|c|}
\hline \multirow[b]{2}{*}{ Rocket Motor } & \multicolumn{9}{|c|}{ Percent by Weight ${ }^{a}$} \\
\hline & $\mathrm{CO}_{2}$ & $\mathrm{CO}$ & $\mathrm{H}_{2} \mathrm{O}$ & $\mathrm{H}_{2}$ & $\mathrm{~N}_{2}$ & $\mathrm{HCl}$ & $\mathrm{Al}_{2} \mathrm{O}_{3}$ & Others & $\begin{array}{l}\text { Molecular } \\
\text { Weight }\end{array}$ \\
\hline Nike & 11.6 & 42.0 & 21.2 & 13.2 & 11.9 & & & 0.1 (unspec.) & 10.0 \\
\hline Zuni & 9.4 & 44.3 & 16.5 & 19.8 & 10.0 & & & & 7.7 \\
\hline Honest John & 9.4 & 44.3 & 16.5 & 19.8 & 10.0 & & & & 7.7 \\
\hline Imp. Honest John & 13.0 & 39.6 & 22.7 & 12.9 & 11.8 & & & & 10.3 \\
\hline Javelin & 5.0 & 28.3 & 13.0 & 1.3 & 11.0 & 13.4 & 28.8 & & 28.3 \\
\hline Little John & 13.0 & 39.6 & 22.7 & 12.9 & 11.8 & & & & 10.3 \\
\hline Mighty Mouse & 29.6 & 49.7 & 6.0 & 1.8 & 11.9 & & & $\begin{array}{l}0.14-\mathrm{CH}_{4} \\
0.9-\mathrm{Pb}\end{array}$ & 24.3 \\
\hline Recruit $^{b}$ & 5.0 & 28.3 & 13.0 & 1.3 & 11.0 & 13.4 & 28.8 & & 28.3 \\
\hline Terrier Booster & 27.8 & 39.7 & 9.4 & 1.7 & 12.7 & & 7.1 & $1.7-\mathrm{Pb}$ & 25.3 \\
\hline Terrier Sustainer & 7.3 & 44.7 & 14.1 & 9.0 & 9.0 & & & $\begin{array}{l}0.68-\mathrm{SO}_{2} \\
0.7-\mathrm{K}_{2} \mathrm{O} \\
0.07-\mathrm{Pb}\end{array}$ & 6.8 \\
\hline HVAR $^{c}$ & 7.3 & 44.7 & 14.1 & 9.0 & 9.0 & & & $\begin{array}{l}0.68-\mathrm{SO}_{2} \\
0.7-\mathrm{K}_{2} \mathrm{O} \\
0.07-\mathrm{Pb}\end{array}$ & 6.8 \\
\hline Hawk & 12.0 & 62.5 & 10.7 & 12.8 & 12.8 & & & & 21.7 \\
\hline
\end{tabular}

a Because of round-off, values may not add to 100 percent exactly

b Javelin used-similar fuels

c Terrier Sustainer used-similar fuels

Data Source: ACTC Final EIS (DA, 1991) 
Table 11. Pollutant Content of Exhaust of Representative Boosters

\begin{tabular}{|c|c|c|c|c|c|c|}
\hline Booster & $\begin{array}{c}\text { Carbon } \\
\text { Monoxide } \\
(\mathrm{kg})\end{array}$ & $\begin{array}{c}\text { Lead } \\
(\mathrm{kg})\end{array}$ & $\begin{array}{c}\text { Aluminum } \\
\text { Oxide } \\
(\mathrm{kg})\end{array}$ & $\begin{array}{c}\text { Hydrogen } \\
\text { Chloride } \\
(\mathrm{kg})\end{array}$ & $\begin{array}{c}\text { Sulfur } \\
\text { Dioxide } \\
\text { (kg) }\end{array}$ & $\begin{array}{c}\text { Other }{ }^{\mathrm{a}} \\
(\mathrm{kg})\end{array}$ \\
\hline Nike & 143 & 1.7 & & & & \\
\hline Zuni & 6.7 & & & & & \\
\hline Honest John & 412 & 5.6 & & . & & \\
\hline Imp. Honest John & 299 & 11.3 & & & . & \\
\hline Javelin & 31 & & 31 & 15 & & \\
\hline Little John & 44 & 1.6 & & & - & \\
\hline Mighty Mouse & 1.3 & 0.02 & & & & \\
\hline Recruit & 34 & & 35 & 16 & & $2.10 \mathrm{MgO}$ \\
\hline Terrier Booster & 217 & 9.3 & 39 & & & \\
\hline Terrier Sustainer & 68 & 0.2 & & & 1.1 & $1.30 \mathrm{KOH}$ \\
\hline HVAR & 4.9 & 0.01 & & & 0.08 & $0.09 \mathrm{KOH}$ \\
\hline Hawk & 28 & & & & & $0.04 \mathrm{CuO}$ \\
\hline
\end{tabular}

a $\mathrm{MgO}=$-magnesium oxide; $\mathrm{KOH}=$ potassium hydroxide; $\mathrm{CuO}=$ =copper oxide Data Source: ACTC Final EIS (DA, 1991)

Booster motors can be used to accelerate a trolley assembly along the cable or as part of the rocket sled track pull-down apparatus. Because the cable is approximately $100 \mathrm{~m}$ (330 ft) above the canyon floor during a typical trolley mission, the dispersion characteristics of the exhaust products are considerably different from the rocket sled track booster case where the boosters travel along a moderately sloping section of the canyon bottom.

Table 12 contains the quantities of the air contaminants that were used in the primary modeling of the booster motor effects. For each contaminant, the quantity used is the maximum of the release of that contaminant either by 25 Zuni or by 25 HVAR boosters. 
Table 12. Maximum Total Release of Air Contaminants by Booster Motors Used for Trolley Acceleration

\begin{tabular}{|lcc|}
\hline \multicolumn{1}{|c}{ Contaminant } & $\begin{array}{c}\text { Maximum Release }^{\mathbf{a}} \\
(\mathrm{kg})\end{array}$ & Booster \\
\hline Carbon monoxide & 168 & Zuni \\
Lead & 0.2 & HVAR \\
Sulfur dioxide & 1.9. & HVAR \\
Potassium hydroxide & 2.3 & HVAR \\
\hline
\end{tabular}

a Values in this table were computed by multiplying the propellant mass by the maximum number of boosters (25) and the percentage of the material in the exhaust. The results are more precise than would be obtained using data in Table 11 which have been rounded for display.

The quantities of contaminants were used as input with INPUFF for the trolley rocket booster scenario. Up to ten tests would be conducted annually involving trolley rocket boosters.

As part of an effort to determine the suitability of the area for hosting a tracer release experiment, the wind patterns at the ACF were studied extensively over a period of more than one year (Church, 1985). It is clear from the project report that the most common wind direction at the test site is southerly, and the next most common direction is northerly. This pattern results from the channeling effect of the canyon. This pattern was observed at all levels within the canyon that were studied. The current modeling assumed southerly winds, and three wind speeds, 1,3 , and $5 \mathrm{~m} / \mathrm{s}(3.3,10$, and $16.4 \mathrm{fps})$, were used. All of the contaminants were assumed to be released within 10 seconds, and the trolley was assumed to be moving along the cable at an average speed of $50 \mathrm{~m} / \mathrm{s}$ (164 fps) during the time that the booster was active. The temperature of the plume at release was assumed to be $1,500 \mathrm{~K}$. It is of little consequence that the rocket burn time is less than 10 seconds. The important detail is that the release is completed in the first interval of the release scenario. That interval in turn is less than the 2-minute interval specified for the dispersion iteration.

On a single run, the model predicts the concentration of the contaminant at user-specified locations. To investigate the concentration of the contaminants with respect to 
NM/AQCR 702, 1-hour average concentrations were computed for a regularly spaced array of sampling points. From these, it was straightforward to compute 8-hour and longer term averages. Computations were carried out for the contarninants released by a cluster of 25 Zuni or HVAR motors. With the above assumptions for the distance over which the rocket burn takes place, and based on the width of the 1-hour average $100 \mu \mathrm{g} / \mathrm{m}^{3}$ contour for carbon monoxide, the plume tends to broaden to less than $0.2 \mathrm{~km}(0.1 \mathrm{mi})$ with $1 \mathrm{~m} / \mathrm{s}(3.3 \mathrm{fps})$ winds, and much less for higher winds. The $100 \mu \mathrm{g} / \mathrm{m}^{3}$ carbon monoxide contour is approximately $1 \mathrm{~km}(0.6 \mathrm{mi})$ long for $1 \mathrm{~m} / \mathrm{s}$ (3.3 fps) winds, and much less for higher winds. The $100 \mu \mathrm{g} / \mathrm{m}^{3}$ level is one-twentieth of the 1-hour Significant Ambient Concentration for carbon monoxide, and the canyon bottom is approximately $1 \mathrm{~km}(0.6 \mathrm{mi})$ in width, so any part of the plume in which the concentration approaches even one-tenth of the Significant Ambient Concentration is contained within the canyon. Therefore, it is reasonable to neglect the canyon terrain for trolley booster rocket modeling. The concentration levels for the other contaminants that would be released by a cluster of 25 HVAR motors are approximately a factor of 75 lower than carbon monoxide for sulfur dioxide and potassium hydroxide, and a factor of 670 lower for lead.

The model also was used to predict the minimum time necessary for the carbon monoxide concentration to return to the ambient value at the Control Building after an event that used 25 Zuni motors. For $1 \mathrm{~m} / \mathrm{s}$ ( $3.3 \mathrm{fps}$ ) winds, that time is less than 20 minutes. For $3 \mathrm{~m} / \mathrm{s}$ (10 fps) winds, the time is less than 10 minutes. The model predicts that the ground-level concentration of carbon monoxide would never reach the level of the Time-Weighted Average (TWA) specified by the ACGIH for exposure averaged over the 8-hour workday 29 [milligram per cubic meter $\left(\mathrm{mg} / \mathrm{m}^{3}\right)$ ]. The ACGIH TWA is more conservative than the Occupational Safety and Health Administration (OSHA) value. Comparison with the 8-hour TWA is a very conservative approach to this assessment. Although the Short Term Exposure Limit (STEL) would be a more appropriate comparison, neither OSHA nor the ACGIH defines STEL for carbon monoxide. When there is no STEL defined, the ACGIH recommends that excursions be limited to 3 times the 8-hour TWA for 30 minutes, and absolutely limited to 5 times the TWA. 
Figures 8 and 9 are site maps with 1 -hour concentration contours for carbon monoxide overlaid. The contours shown were computed for $3 \mathrm{~m} / \mathrm{s}(10 \mathrm{fps})$ and $1 \mathrm{~m} / \mathrm{s}(3.3 \mathrm{fps})$ upcanyon and down-canyon winds.

The model also is useful to tabulate the maximum predicted concentrations for selected locations in and near the test site. Table 13 is such a listing. The values in the table apply only if the wind is blowing directly from the trolley booster toward the facility. Although slightly higher concentrations can occur for lighter wind conditions, the values were tabulated for $3 \mathrm{~m} / \mathrm{s}$ (10 fps), which is near the average wind speed at the site.

Table 13. Maximum Concentrations of Air Contaminants in $\mu \mathrm{g} / \mathrm{m}^{3}$ from Trolley Boosters at Selected Locations In and Near the Test Site

\begin{tabular}{|lccccc|}
\hline Facility & $\begin{array}{c}\mathrm{CO} \\
\text { 1-hour }\end{array}$ & $\begin{array}{c}\mathrm{CO} \\
\text { 8-hour }\end{array}$ & $\begin{array}{c}\mathrm{Pb} \\
\text { 3-month }\end{array}$ & $\begin{array}{c}\mathrm{SO}_{2} \\
\text { 3-hour }\end{array}$ & $\begin{array}{c}\mathrm{KOH} \\
\text { 8-hour }\end{array}$ \\
\hline Zuni & & & & & \\
Control & 96.4 & 12.1 & n.a. & n.a. & n.a. \\
Burn & 91.4 & 11.4 & n.a. & n.a. & n.a. \\
Spring & 91.8 & 11.5 & n.a. & n.a. & n.a. \\
Firing Range & 91.4 & 11.4 & n.a. & n.a. & n.a. \\
9849 & 84.7 & 10.6 & n.a. & n.a. & n.a. \\
9925 & 71.5 & 8.9 & n.a. & n.a. & n.a. \\
9990 & 62.1 & 7.8 & n.a. & n.a. & n.a. \\
& & & & & \\
HVAR & & & & & 0.162 \\
Control & 70.5 & 8.8 & 0.000067 & 0.384 & 0.154 \\
Burn & 66.8 & 8.4 & 0.000064 & 0.364 & 0.154 \\
Spring & 67.1 & 8.4 & 0.000063 & 0.365 & 0.154 \\
Firing Range & 66.8 & 8.4 & 0.000064 & 0.364 & 0.142 \\
9849 & 62.0 & 7.7 & 0.000059 & 0.337 & 0.120 \\
9925 & 52.3 & 6.5 & 0.000049 & 0.284 & \\
9990 & 45.4 & 5.7 & 0.000043 & 0.247 & 0.104 \\
& & & & & \\
\hline
\end{tabular}

Note: Predictions were made with INPUFF for a wind speed of $3 \mathrm{~m} / \mathrm{s}$ (10 fps). Values apply only if the wind direction is from the cable toward the facility. n.a. = not applicable. 

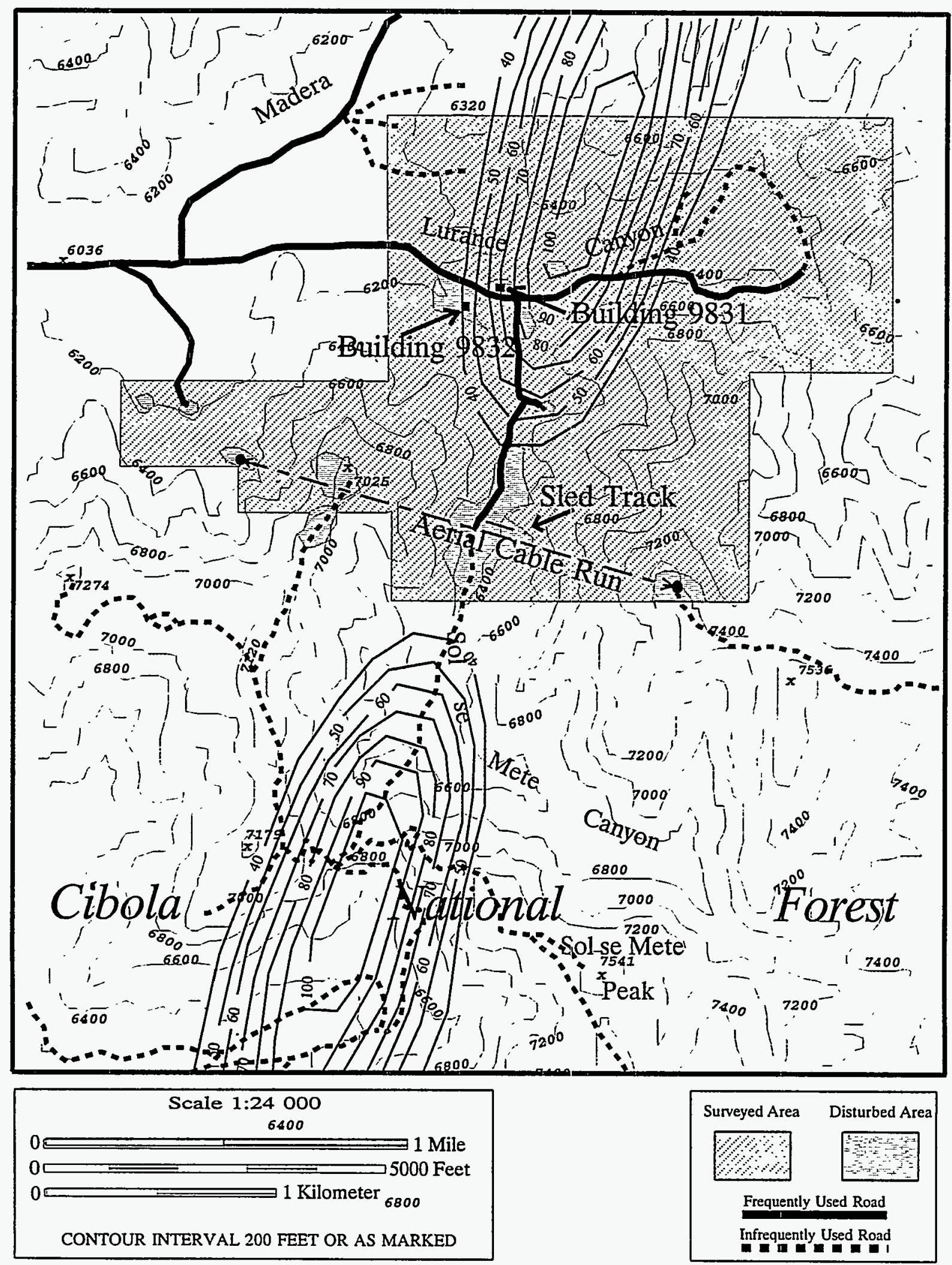

Figure 8. One-Hour Average Carbon Monoxide Concentration Contours $\left(\mu \mathrm{g} / \mathrm{m}^{3}\right)$; Wind Speec $1 \mathrm{~m} / \mathrm{s}$ (for 25 Zuni motors used for trolley accelerations) 

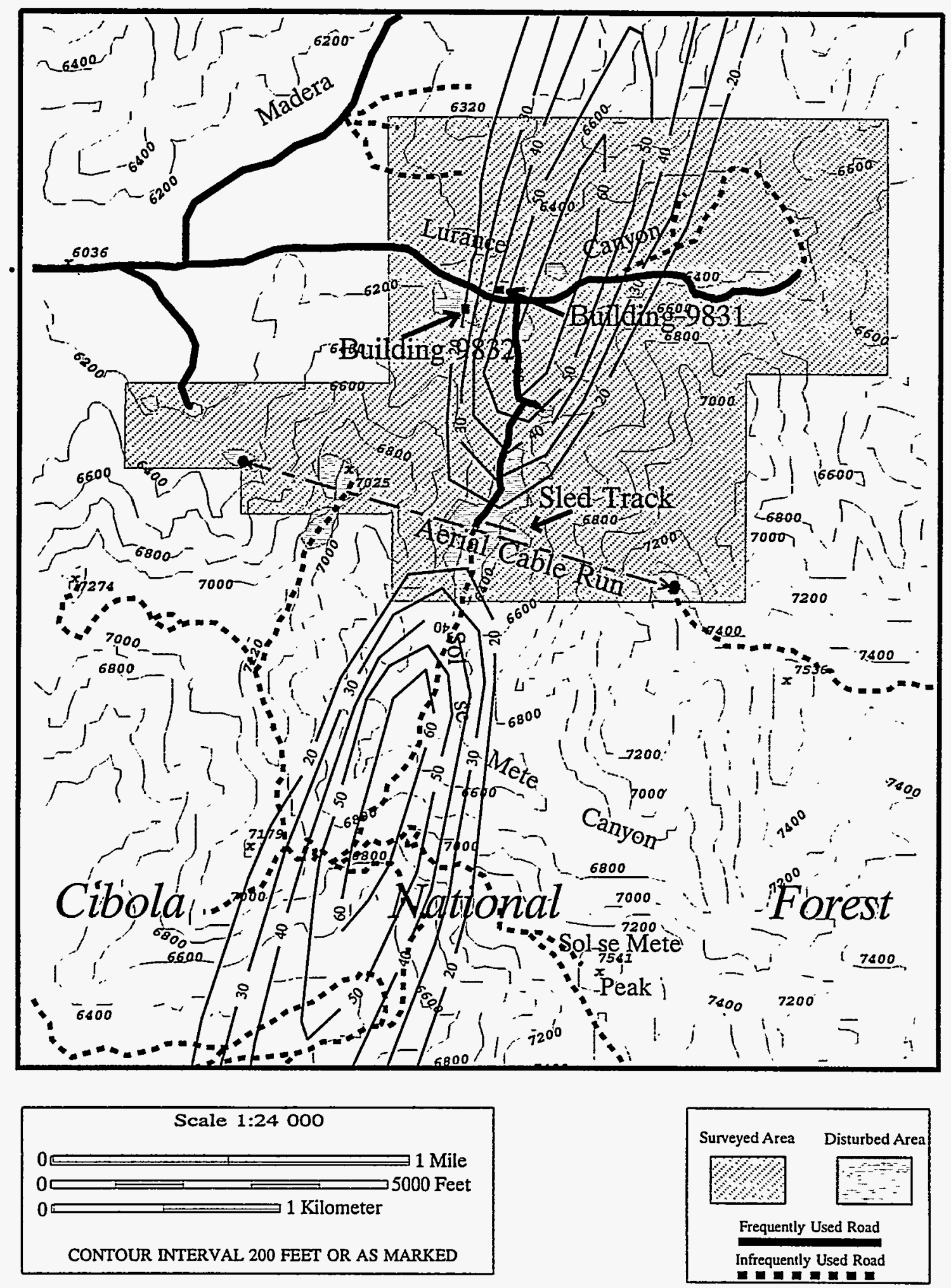

Figure 9. One-Hour Average Carbon Monoxide Concentration Contours $\left(\mu \mathrm{g} / \mathrm{m}^{3}\right)$; wind Speed $3 \mathrm{~m} / \mathrm{s}$ (for 25 Zuni motors used for trolley acceleration) 
With the selection of booster motors limited to Zunis and HVARs, annual lead emissions from trolley boosters would not exceed $2.5 \mathrm{~kg}(5.5 \mathrm{lb})$ per year.

Boosters used for the sled-driver pull-down tests would be used in up to 35 tests annually. Again, operations are limited to Zuni and HVAR boosters. Clusters of up to 11 units were assumed. The carbon monoxide emission for the Zuni was used in the modeling, and the emissions of lead, sulfur dioxide, and potassium hydroxide for the HVAR were used because they are larger. The boosters accelerate the pull-down apparatus along a track that is $244 \mathrm{~m}$ (800 ft) long. The air contaminants were assumed to be initially dispersed along this track. The dispersal was assumed to be at ground level. Table 14 lists the maximum predicted concentration of each contaminant at the Control Building for $3 \mathrm{~m} / \mathrm{s}$ (10 fps) southerly winds.

\section{Table 14. Maximum Predicted Concentrations of Air Contaminants at the Control Building Resulting from a Cluster of 11 Zuni or HVAR Boosters under $3 \mathrm{~m} / \mathrm{s}$ Wind Conditions}

\begin{tabular}{|lc|}
\hline \multicolumn{1}{|c|}{ Contaminant } & $\begin{array}{c}\text { Concentration } \\
\mu \mathrm{g} / \mathrm{m}^{3}\end{array}$ \\
\hline Carbon monoxide (1 hour) & 117 \\
Carbon monoxide (8 hours) & 14.6 \\
Lead (3 months) & 0.00081 \\
Sulfur dioxide (3 hours) & 0.47 \\
Potassium hydroxide (8 hours) & 0.20 \\
\hline
\end{tabular}

With the assumption that no more than one mission utilizing either trolley boosters or pulldown boosters would occur in a day, none of the contaminant concentrations could approach any regulatory limit for concentration. Table 15 summarizes the maximum annual emissions that could occur with both trolley and pull-down boosters, assuming either 25 Zunis or 25 HVARs for the trolley boosters, and either 11 Zunis or 11 HVARs for the pull-down apparatus. The use of these quantities of rockets for all annual tests is extremely unlikely. 
Even at the maximum usage rates, none of the emissions approaches quantities of regulatory concern.

Table 15. Maximum Release Scenario Annual Emissions of Air Contaminants Resulting from Trolley and Pull-Down Boosters

\begin{tabular}{|lc|}
\hline & \multicolumn{1}{|c|}{$\begin{array}{c}\text { Maximum Release Scenario } \\
\text { Contaminant }\end{array}$} \\
\hline Carbon monoxide & 4.7 \\
Lead & 0.007 \\
Sulfur oxides & 0.056 \\
Potassium hydroxide & 0.063 \\
\hline
\end{tabular}

\subsubsection{Explosive Test Devices}

Three types of tests are considered in this section

- detonation of up to $1.8 \mathrm{~kg}(4 \mathrm{lb})$ of high explosive material (up to 100 tests per year);

- detonation of up to 454-kg (1000 lb) high-explosive devices (one test per year); and

- firing of 120 inert rounds from a 3-inch gun at a rate of up to 3 per hour over a 5-day period or 100 inert rounds from a $20-\mathrm{mm}$ gun at a rate of 3,000 rounds per minute ( 1 test per year).

Explosive devices containing $1.8 \mathrm{~kg}(4 \mathrm{lb})$ are detonated above a simulated target placed on a graded and graveled test pad within the test arena. Therefore, these devices produce essentially no ground cratering or particulate matter. The 454-kg $(1,000 \mathrm{lb})$ devices are assumed to be concussion bombs detonated at the ground surface. It will be assumed that the propellant used in the 3-inch and 20-mm guns can be treated as a high-explosive material for the purpose of estimating the air emissions. Each 3-inch round uses $2.0 \mathrm{~kg}(4.4 \mathrm{lb})$ of propellant and primer for a total of $240 \mathrm{~kg}(528 \mathrm{lb})$, and each $20-\mathrm{mm}$ round uses $0.0423 \mathrm{~kg}$ 
$(0.093 \mathrm{lb})$ of propellant for a total of $4.23 \mathrm{~kg}(9.3 \mathrm{lb})$ for 100 rounds. The propellant charge for the 3-inch gun also contains $0.030 \mathrm{~kg}(0.066 \mathrm{lb})$ of metallic lead and less than $10 \mathrm{mg}$ $(0.0022 \mathrm{lb})$ each of elemental mercury, potassium, and antimony. At the ACF, both types of guns are used only with non-exploding projectiles. Gaseous emissions can be estimated using EPA factors (EPA, 1985) that are summarized in Table 16. The emission factors are appropriate for the explosive material TNT which is commonly used as a proxy for other explosives. The maximum annual use of explosive material would be approximately $1,100 \mathrm{~kg}$ $(2,420 \mathrm{lb})$. The total includes $240 \mathrm{~kg}(526 \mathrm{lb})$ of gun propellant.

\section{Table 16. Emission Factors for Air Contaminants Produced by High Explosives and Estimated Total Annual Emissions}

\begin{tabular}{|lcc|}
\hline Contaminant & $\begin{array}{c}\text { Emission Factor } \\
\left(\mathrm{lb}_{\text {ton }}{ }^{2}\right)\end{array}$ & $\begin{array}{c}\text { Annual Emission } \\
\left(\text { tons }^{2}\right)\end{array}$ \\
\hline Carbon monoxide & 796 & 0.48 \\
Ammonia & 29 & 0.017 \\
Methane & 14.3 & 0.009 \\
Hydrogen cyanide & 27 & 0.016 \\
Other hydrocarbons & 122 & 0.074 \\
Lead & $-\mathrm{b}-$ & 0.004 \\
\hline
\end{tabular}

a The emission factors and annual emissions are reported in tons because the regulations are based on English units.

b Lead emission is based on the actual lead content of the propellant.

Data Source: EPA, 1985

Concentrations of the atmospheric contaminants produced by the small explosive devices are minimal. For example, each such device would produce 1.0 percent of the carbon monoxide of the pull-down boosters; hence, the concentrations of the contaminants would be minimal. This also is true of the 3 -inch and $20-\mathrm{mm}$ guns. The $20-\mathrm{mm}$ gun would be vehicle mounted. The production of carbon monoxide by the firing of one round from the gun would be approximately equivalent to the engine emissions by the gun carriage for travel over a $2.7-\mathrm{km}$ 
(1.7-mile) distance. The total annual lead emissions from the 3-inch gun would be less than the reportable quantity, $4.54 \mathrm{~kg}(10 \mathrm{lb})$, for a single event.

A reasonable methodology to estimate the concentration of pollutants in the exhaust gas plume from weapons firing is to treat the plume behavior as an adiabatic expansion process into a spherical volume. The gas temperature drops as it expands, and the expansion is complete when its temperature reaches the ambient level. The volume can be computed with a simple ideal gas formulation. Using a realistic estimate of $1,800 \mathrm{~K}$ for the initial plume temperature, the computed equivalent radius of the sphere is about $11.3 \mathrm{~m}(37.1 \mathrm{ft})$. That value was used to estimate the initial concentrations of pollutants in the plume. Those concentrations along with the ACGIH 8-hour time weighted average threshold limit values are shown in Table 17. ACGIH 8-hour TWAs are shown because short term exposure limits are not defined for some of the materials. For lead and $\mathrm{CO}$, the initial concentrations in the plume exceed the levels of ACGIH 8-hour TWAs. Short term exposure limits have not been defined for these contaminants. When STELs are not defined, the ACGIH recommends that the exposure be limited to 3 times the 8-hour TWA for a maximum of 30 minutes, and absolutely limited to 5 times the TWA. Even with very light winds, the potential exposure time to the gun crew would be short, approximately 40 seconds with $0.5 \mathrm{~m} / \mathrm{s}$ (1.6 fps) wind. The exposure to all contaminants except lead would be below these recommended limits. For lead, neither the value for 8-hour TWA nor 3 times TWA for 30 minutes would be exceeded. However, a value of 5 times the TWA would be exceeded within the plume; hence, gun crewmen should not be directly exposed to the undiluted smoke plume unless they are using appropriate respiratory protective gear for lead in particulate form. It is expected that up to 3 firings would occur per hour. At that rate, neither the value for the 8-hour TWA nor 3 times the TWA for 30 minutes of exposure would be exceeded.

The concentrations of the contaminants at the ACF Control Building were predicted using the INPUFF model for the case of sustained firing at the rate of 3 rounds per hour with an assumed wind speed of $3 \mathrm{~m} / \mathrm{s}$ (10 fps). The results are summarized in Table 18 . 
Table 17. Predicted Initial Concentrations of Air Contaminants and Potential 8-hour Time Weighted Average Exposure Levels

\begin{tabular}{|lccc|}
\hline Contaminant & $\begin{array}{c}\text { Initial Plume } \\
\text { Concentration } \\
\mathrm{mg} / \mathrm{m}^{3}\end{array}$ & $\begin{array}{c}\text { 8-hour TWA } \\
\mathrm{mg} / \mathrm{m}^{3}\end{array}$ & $\begin{array}{c}\text { ACGIH 8-hour TWA } \\
\mathrm{mg} / \mathrm{m}^{3}\end{array}$ \\
\hline Lead & 5.0 & 0.007 & 0.05 \\
Carbon monoxide & 133 & 0.18 & 29 \\
Ammonia & 4.8 & 0.007 & 17 \\
Methane & 2.4 & 0.003 & $-\mathrm{a}-$ \\
Hydrogen cyanide & 4.5 & 0.006 & 5 \\
Hydrocarbons & 20.3 & 0.028 & $890^{\mathrm{b}}$ \\
\hline
\end{tabular}

a Methane is a simple asphyxiant. Total oxygen content of the air must not drop below 18 percent.

b The value for gasoline was used as a proxy because it is a mixture of hydrocarbons.

Table 18. Predicted Average Concentrations of Air Contaminants at the ACF Control Building Resulting from Sustained 3-Round per Hour Firing of the 3-inch Gun under $3 \mathrm{~m} / \mathrm{s}$ Wind Conditions

\begin{tabular}{|lcc|}
\hline \multicolumn{1}{|c}{ Contaminant } & $\begin{array}{c}\text { Predicted Concentration } \\
\left(\mu \mathrm{g} / \mathrm{m}^{3}\right)\end{array}$ & Averaging time \\
\hline Carbon monoxide & 12.7 & 1 hour \\
Carbon monoxide & 12.7 & 8 hours \\
Ammonia & 0.46 & 8 hours \\
Methane & 0.23 & 8 hours \\
Hydrogen cyanide & 0.43 & 8 hours \\
Other hydrocarbons & 1.95 & 8 hours \\
\hline
\end{tabular}


The large explosive devices, up to $454 \mathrm{~kg}(1,000 \mathrm{lb})$, would produce large quantities of atmospheric contaminants. Calculations for gaseous components are straightforward, but the amount of particulate matter that would be produced depends strongly on the soil characteristics and the type of detonation.

Because Sol se Mete Spring discharges continuously, the subsurface soil at the test arena is relatively moist through most of the year. Also, considerable coarse and sandy soil has been used to back-fill around test facilities at the ACF. Therefore, the silt content is quite small. Using the conventional weapons effects model, ConWep, which was developed by the U.S. Army Engineer Waterways Experiment Station (Hyde, 1988), a surface explosion of $454 \mathrm{~kg}(1,000 \mathrm{lb})$ of high explosive material on moist sandy soil would eject approximately $68 \mathrm{~m}^{3}\left(2,401 \mathrm{ft}^{3}\right)$ of material. For each cubic meter, approximately $1,500 \mathrm{~kg}(3,300 \mathrm{lb})$ of material would become airborne. However, because of the low silt content less than 0.1 percent of the airborne material likely would be in the form of particles of $10 \mu \mathrm{m}$ or smaller diameter. Larger particles would settle out quickly and produce no effects beyond the immediate area of the explosion. Detonation above the surface or on a concrete or gravel pad would produce a smaller quantity of particulate matter. Thus, the maximum annual production of particulates $\left(\mathrm{PM}_{10}\right)$ would be $102 \mathrm{~kg}(224 \mathrm{lb}$ or $0.11 \mathrm{ton})$.

The adiabatic expansion method can be applied to predict the volume of the initial distribution of contaminants. The result is $1.35 \times 10^{6} \mathrm{~m}^{3}$ for a $454 \mathrm{~kg}(1,000 \mathrm{lb})$ detonation which

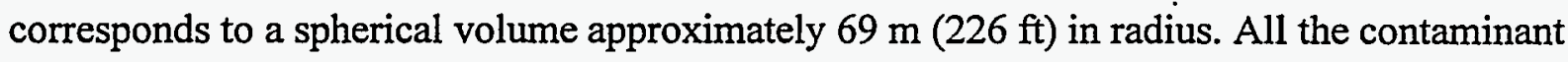
materials would be initially well dispersed within this volume. The further dispersion of the materials was predicted using INPUFF. Table 19 lists the predicted concentrations of the major pollutants over appropriate averaging periods at the Control Building with an assumed wind speed of $3 \mathrm{~m} / \mathrm{s}$ (10 fps). 
Table 19. Predicted Average Concentrations of Air Contaminants at the ACF Control Building Resulting from a 454-kg (1,000-lb) Explosive Device Under $3 \mathrm{~m} / \mathrm{s}$ Wind Conditions

\begin{tabular}{|lcc|}
\hline \multicolumn{1}{|c}{ Contaminant } & $\begin{array}{c}\text { Predicted Concentration } \\
\left(\mu \mathrm{g} / \mathrm{m}^{3}\right)\end{array}$ & Averaging Time \\
\hline Carbon monoxide & 119 & 1 hour \\
Carbon monoxide & 14.8 & 8 hours \\
Ammonia & 0.54 & 8 hours \\
Methane & 0.27 & 8 hours \\
Hydrogen cyanide & 0.50 & 8 hours \\
Other hydrocarbons & 2.28 & 8 hours \\
PM $_{10}$ & 2.8 & 24 hours \\
\hline
\end{tabular}

\subsubsection{Contaminants from Vehicle Operations}

Vehicles produce air contaminants through two separate mechanisms: fugitive dust and engine exhaust emissions. The fugitive dust emission is highly dependent on such factors as the weight of the vehicle, the number of wheels in contact with the road, and the speed. The exhaust emissions consist of both gases and particulates. An estimate of the amounts and types of vehicular traffic associated with the test activities was provided by SNL. The lengths of the road segments were scaled from careful measurements made with 1:24,000 scale topographical maps. This information is summarized in Tables 20, 21, and 22. (Note: English units are used in these three tables because emission estimation procedures used by the EPA are based on English units.)

Table 20. Lengths of Paved and Unpaved Road Segments Associated with the ACF

\begin{tabular}{|lccc|}
\hline \multicolumn{1}{|c}{ Segment } & Paved & Unpaved & Total \\
\hline Area III-Bldg. 9831 & 2.6 & 5.6 & 8.2 \\
Bldg. 9831-Test Arenas & & 1.1 & 1.1 \\
Bldg. 9831-West Cable Anchor & & 3.1 & 3.1 \\
\hline
\end{tabular}


Table 21. Estimated Vehicular Traffic Associated with Operation of the ACF

\begin{tabular}{|llcr|}
\hline \multicolumn{1}{|c}{ Segment } & \multicolumn{1}{c}{ Vehicle Type/Road } & $\begin{array}{c}\text { Round } \\
\text { Trip Frequency }\end{array}$ & $\begin{array}{c}\text { Annual } \\
\text { Mileage }\end{array}$ \\
\hline Area III-Bldg. 9831 & SNL light, paved & $6 /$ day & 7,488 \\
Area III-Bldg. 9831 & SNL light, unpaved & $6 /$ day & 16,128 \\
Area III-Bldg. 9831 & Customer light, paved & $1 /$ day & 1,248 \\
Area III-Bldg. 9831 & Customer light, unpaved & $1 /$ day & 2,688 \\
Bldg. 9831-Test Arenas & SNL light, unpaved & $10 /$ day & 5,280 \\
Area III-Test Arenas & SNL heavy, paved & $30 /$ year & 156 \\
Area III-Test Arenas & SNL heavy, unpaved & $30 /$ year & 402 \\
Bldg. 9831-West Anchor & SNL light, unpaved & $1 /$ month & 74 \\
\hline
\end{tabular}

Table 22. Assumed Vehicle Characteristics

\begin{tabular}{|c|c|c|c|c|}
\hline \multirow[b]{2}{*}{ Type } & \multirow[b]{2}{*}{$\begin{array}{l}\text { Weight } \\
\text { (tons) }\end{array}$} & \multirow[b]{2}{*}{$\begin{array}{l}\text { No. of } \\
\text { Wheels }\end{array}$} & \multicolumn{2}{|c|}{ Speed $(\mathrm{mi} / \mathrm{hr})^{\mathrm{a}}$} \\
\hline & & & Paved & Unpaved \\
\hline SNL light & 1.5 & 4 & 45 & 25 \\
\hline SNL heavy & 30 & 18 & 45 & 10 \\
\hline Customer light & 1.5 & 4 & 45 & 25 \\
\hline
\end{tabular}

a The speed on the road to the west cable anchor is assumed to be $15 \mathrm{mi} / \mathrm{hr}$.

Transportation of personnel between the test site and Area III is consolidated into 10- to 15passenger vehicles. Normally, there is one trip to the test area early in the work day and a trip back to the headquarters building at day's end. Overall, the traffic tends to be spread fairly uniformly over the work day. Transportation of heavy equipment can occur on any work day. 
It is assumed in the calculations below that there would never be more than a single heavy vehicle trip in one day. At a rate of 30 such trips per year, this assumption is reasonable.

Vehicle emissions of both fugitive dust and exhaust products were estimated using EPA approved methods. Fugitive dust emission from vehicles operating on paved roads was estimated using the following formula developed by EPA (EPA, 1985, Section 11.2.1):

$$
E=0.077 I(4 / n)(s / 10)(L / 1000)(W / 3)^{0.7} \text { pounds/VMT }
$$

where

$E=$ fugitive dust emissions per vehicle mile traveled (pounds/mile)

$I=$ industrial augmentation factor (assume 2 [dimensionless] for 2-lane, open desert road)

$n=$ number of lanes (assume 2)

$s=$ surface silt content of road in percent (assume 4 percent)

$L=$ surface dust loading (assume typical value of 5 pounds $/$ mile)

$W=$ mean vehicle weight (tons)

Likewise, emission of fugitive dust from vehicles operating on unpaved roads was estimated using the following formula developed by EPA (EPA, 1985):

$$
E=k(5.9)(s / 12)(S / 30)(W / 3)^{0.7}(w / 4)^{0.5}((365-P) / 365)
$$

where

$E=$ fugitive dust emissions per vehicle mile traveled (pounds/mile)

$k=$ particle size factor (assume 0.36 for particles $\leq 10 \mu \mathrm{m}$ )

$s=$ silt content of road surface in percent (local soils contain about 15 percent silt; road surface will be smaller; assume 5 percent)

$S=$ mean vehicle speed (miles per hour)

$W=$ mean vehicle weight (tons)

$w=$ mean number of wheels

$P=$ annual number of days with at least 0.01 inches of precipitation (use 60 which is the average value at the Albuquerque International Airport)

The values used for the various parameters are listed in Table 22 when they are known. For parameters that were not known or which might be subject to yearly, seasonal, or daily variation, representative values were assumed. For example, a parameter in the unpaved road formula is the number of days during the year on which at least 0.0254 centimeter $(\mathrm{cm})$ 
[0.01 inch (in)] of precipitation falls. Detailed, long-term climatological data have not been collected at the test site, but the average value at the Albuquerque International Airport is 60 (SNL 1990). Nearer the ACR site, the value probably would be larger. Nevertheless, the value 60 was used. Likewise, the particle size factor and silt content of the road surface are required in the formula. These factors change with time and when road maintenance is performed, so typical values were assumed. All assumed values are indicated in the parameter definitions following the formulas.

The emission factors that were computed to estimate the air quality impact of vehicleproduced fugitive dust associated with the ACF operation are summarized in Table 23.

Table 23. Computed Emission Factors for Fugitive Dust

\begin{tabular}{|lccl|}
\hline Vehicle Type & Road Type & $\begin{array}{c}\text { Speed } \\
(\mathrm{mi} / \mathrm{hr})\end{array}$ & $\begin{array}{c}\text { Emission } \\
(\mathrm{lb} / \mathrm{mi})\end{array}$ \\
\hline Light & Paved & 45 & 0.00038 \\
Heavy & Paved & 45 & 0.0031 \\
Light & Unpaved & 25 & 0.38 \\
Light & Unpaved & 15 & 0.23 \\
Heavy & Unpaved & 10 & 2.62 \\
\hline
\end{tabular}

Exhaust emissions were estimated using Table 24. These data also were developed by the EPA (EPA, 1985). 
Table 24. Standard EPA Exhaust Emission Factors Based on

"High Altitude - 1990 Standards"

\begin{tabular}{|lcc|}
\hline & \multicolumn{2}{c|}{$\begin{array}{c}\text { 1990 Standards } \\
\text { (grams/mile) }\end{array}$} \\
\cline { 2 - 3 } \multicolumn{1}{c}{ Contaminant } & Light Vehicles & Trucks \\
\hline Carbon monoxide & 2.8 & 17.8 \\
Hydrocarbons & 0.27 & 2.9 \\
Nitrogen oxides & 0.24 & 11.2 \\
Particulates & 0.25 & 0.81 \\
Sulfur oxides & 0.13 & 1.7 \\
\hline
\end{tabular}

For the vehicle types, usage, and assumed conditions, the total annual emissions of both exhaust products and fugitive dust are summarized in Table 25 . These values were computed by multiplying the vehicle miles traveled by the appropriate emission factor for each pollutant and then summing for the vehicle and road types.

Table 25. Annual Air Contaminant Emissions Due to Operation of Vehicles at the $\mathrm{ACF}$

\begin{tabular}{|lc|}
\hline \multicolumn{1}{|c|}{ Contaminant } & $\begin{array}{c}\text { Annual Production } \\
\text { (tons) }\end{array}$ \\
\hline Fugitive dust & 5.10 \\
Carbon monoxide & 0.11 \\
Hydrocarbons & 0.11 \\
Nitrogen oxides & 0.015 \\
Sulfur oxides & 0.0057 \\
Exhaust particulates & 0.0094 \\
\hline
\end{tabular}


It is obvious from inspection of a site map (Figure 2) that the road to the ACF site is not perfectly straight. For modeling the large-scale behavior of contaminant dispersion, it is a common practice to approximate a road with straight segments. It is possible to select these idealized segments in such a way that no point on the real road deviates more than a predetermined tolerance from the idealized straight road segments. On a scale of tens to hundreds of meters from the road, segments $0.5-1.0 \mathrm{~km}$ ( 0.3 to 0.6 mile) in length can be very accurately approximated as straight lines. The roads to the ACF can be approximated very naturally with such a series of straight segments. The predominant considerations in modeling the dispersion of contaminants on this scale are the wind speed and direction relative to the road and the local topography. For the purposes of this analysis, typical low wind speed conditions were assumed. Low wind speeds produce the highest concentrations of contaminants near the source. The direction of the wind with respect to the road plays a role in determining the contaminant levels. Wind along the road tends to produce somewhat higher concentrations near the road than perpendicular wind, but concentrations fall off more quickly with distance. In part, this is because the contaminants are distributed on both sides with parallel winds, but are distributed on only one side with perpendicular winds. Local topography can play a role in some situations such as if the road is confined to a narrow canyon.

The road that services the ACF follows the bottoms of Arroyo del Coyote and Lurance Canyon before turning into Sol se Mete Canyon. Both Arroyo del Coyote and Lurance Canyon are wide enough that the canyon topography is unlikely to affect significantly the contaminant concentrations near the road. Concentrations of regulatory consequence are likely to be found only very near the road. Even in the narrower Sol se Mete Canyon, the canyon walls rise at a rate of only about $50 \mathrm{~m}(164 \mathrm{ft})$ in the first $200 \mathrm{~m}(656 \mathrm{ft})$ of lateral displacement from the canyon bottom, and the effective width of the canyon is about $1 \mathrm{~km}$ $(0.6 \mathrm{mi})$. A flat road approximation is reasonable if the first iteration of the dispersion modeling predicts that the contaminant concentrations drop below levels of regulatory concern well within $500 \mathrm{~m}(1,640 \mathrm{ft})$ from the road. 
The pollutant emission rate was computed by dividing the total daily emission of each contaminant by the length of the road over which the material is emitted and by the length of the work day. This methodology implicitly assumes a uniform rate over the work day. In determining the compliance of the facility with Bernalillo County, New Mexico and Federal air quality regulations, 1-hour, 3-hour, 8-hour, 24-hour, and annual average values are required for various contaminants. The modeling methodology yields the work day average for the vehicle-released contaminants. The annual averages were computed from the average work day emissions of the contaminants by further averaging over the entire 24-hour day and the full year. Shorter term averages (1-hour, 3-hour, 8-hour, and 24-hour) were computed using the estimated emissions for a day including both the typical daily traffic and also the less typical heavy vehicle traffic.

Another source of particulates that must be considered is wind erosion of the exposed unpaved road surfaces. On the average, the unpaved roads are about $4 \mathrm{~m}(13.1 \mathrm{ft})$ wide. Therefore, the total area of the unpaved roads is approximately 6.5 hectares (16 acres). The emission factor can be estimated using the formula of Bohn, Cuscino, and Cowherd (1978).

$$
E=3,400 \frac{\left(\frac{e}{50}\right)\left(\frac{S}{15}\right)\left(\frac{f}{25}\right)}{\left(\frac{P-E}{50}\right)^{2}}
$$

where

$E=$ the emission factor in pounds per acre-year for particles smaller than $30 \mu \mathrm{m}$ in diameter

$e \quad=$ the surface erodibility

$S=$ the silt content

$f=$ the percentage of the time wind speed exceeds $12 \mathrm{mph}$

$P-E=$ the Thornthwaite precipitation-evaporation index

Although the surface erodibility and silt content have not been determined for the unpaved roads leading to the site, they are low because of the high gravel content of the surface. A reasonable estimate of the erodibility is $454 \mathrm{~kg}(1,000 \mathrm{lb})$ per acre per year. The silt content of undisturbed soils in the ACF area is about 15 percent, so 5 percent for the roads is a 
reasonable estimate of the average because of the gravel content and the continual removal by vehicles. A Thornthwaite precipitation-evaporation index of 25 percent is appropriate for the soils in the area, and the mean wind speed can be assumed to exceed $5.4 \mathrm{~m} / \mathrm{s}$ (17.6 fps) for 20 percent of the time. This yields a value of $16 \mathrm{~kg} \mathrm{(36} \mathrm{lb)} \mathrm{per} \mathrm{acre} \mathrm{per} \mathrm{year,} \mathrm{or} \mathrm{a} \mathrm{total}$ of about $263 \mathrm{~kg}$ ( 0.29 tons) per year in total. On an annual basis, the amount produced by this source of fugitive dust would be about 6 percent of the fugitive dust produced by vehicles. Averaged over the entire year, this corresponds to a production of about $0.53 \mu \mathrm{g} / \mathrm{m} / \mathrm{s}$ (micrograms per meter per second). Because it has been assumed that the wind speed exceeds $5.4 \mathrm{~m} / \mathrm{s}$ (17.6 fps) about 20 percent of the time, it is reasonable to assume for estimating purposes that the peak dust production rate is a constant rate on one-fifth of the days. That rate is $2.65 \mu \mathrm{g} / \mathrm{m} / \mathrm{s}$.

Table 26 is a compilation of the emission rates in $\mu \mathrm{g} / \mathrm{m} / \mathrm{s}$ for each of the air contaminants produced by vehicular traffic. The values were derived from the total daily emission for an average day and for a peak day (heavy vehicle usage). The average daily emissions were used to compute the annual concentration levels, and the peak daily emissions were used for the shorter term averages. Rates of fugitive dust production by wind interaction with the roads were added to the vehicle rates to perform the modeling.

Table 26. Emission Rates of Vehicle-Produced Air Contaminants and Wind-Produced Fugitive Dust

\begin{tabular}{|lcc|}
\hline Contaminant & $\begin{array}{c}\text { Yearly Average } \\
\text { Work Day Rate } \\
(\mu \mathrm{g} / \mathrm{m} / \mathrm{s})\end{array}$ & $\begin{array}{c}\text { Peak Average } \\
\text { Work Day Rate } \\
(\mu \mathrm{g} / \mathrm{m} / \mathrm{s})\end{array}$ \\
\hline Vehicle-Produced: & & \\
Fugitive dust & 55.5 & 88.8 \\
Carbon monoxide & 0.88 & 1.65 \\
Hydrocarbons & 0.091 & 0.20 \\
Nitrogen oxides & 0.122 & 0.51 \\
Sulfur oxides & 0.075 & 0.11 \\
Exhaust particulates & 0.045 & 0.12 \\
Wind-Produced: & & \\
Fugitive dust & 0.53 & 2.65 \\
\hline
\end{tabular}


Calculations were performed both for the case of wind parallel to the road and for wind perpendicular to the road. The modeling was performed for wind speeds of 1,3 , and $5 \mathrm{~m} / \mathrm{s}$ (3.3, 10, and $16.4 \mathrm{fps})$. Three meters per second (9.8 fps) is approximately the yearly average wind speed at the Albuquerque International Airport. The results of the modeling are presented in Table 27. The results are presented as the minimum distance from the road at which the concentration drops to the New Mexico Significant Ambient Concentration level. Distances from the road at which the $\mathrm{PM}_{10}$ concentrations drop to the annual Significant Ambient Concentration are greater than the distances for the 24-hour level because the annual standard is one-fifth of the 24-hour standard. The values reported in Table 26 are for winds parallel to the road. With perpendicular winds, all contaminants travel to one side of the road, so parallel winds provide a better picture of long-terrn average effects.

As seen in Table 27 , with $1 \mathrm{~m} / \mathrm{s}(3.3 \mathrm{fps})$ winds, the annual average fugitive dust concentration drops to the $1 \mu \mathrm{g} / \mathrm{m}^{3}$ level at $26 \mathrm{~m}(85.3 \mathrm{ft})$ from the road. For the purpose of exploring the effects of higher traffic levels, model calculations also were performed for the case of traffic at 3 times the rate used in the basic modeling. These calculations indicate that, with $3 \mathrm{~m} / \mathrm{s}$ (10 fps) winds, the fugitive dust concentration drops to $1 \mu \mathrm{g} / \mathrm{m}^{3}$ on an annual average basis at $60 \mathrm{~m}$ (197 ft) from the road. Assuming most ACF vehicle usage is roughly one-third of the traffic density along the roadway to the ACF, this 3-fold higher level may be more indicative of the overall average dust level produced from all SNL, DOE, and Air Force users. 


\section{Table 27. Distance from the Roads at which Concentrations Drop to the New Mexico Significant Ambient Concentration Level}

\begin{tabular}{|c|c|c|c|c|}
\hline Contaminant $^{\mathrm{a}}$ & $\begin{array}{c}\text { Averaging } \\
\text { Time }\end{array}$ & $\begin{array}{c}\text { Concentration } \\
\left(\mu \mathrm{g} / \mathrm{m}^{3}\right)\end{array}$ & $\begin{array}{l}\text { Wind Speed } \\
(\mathrm{m} / \mathrm{s})\end{array}$ & $\begin{array}{l}\text { Distance } \\
\text { (m) (ft) }\end{array}$ \\
\hline \multirow{6}{*}{$\mathrm{PM}_{10}$} & 1 year & 1 & 1 & $26(85.3)$ \\
\hline & 24 hours & 5 & 1 & $14(46)$ \\
\hline & 1 year & 1 & 3 & $17(55.8)$ \\
\hline & 24 hours & 5 & 3 & $8(26.2)$ \\
\hline & 1 year & 1 & 5 & $10(32.8)$ \\
\hline & 24 hours & 5 & 5 & $1(3.3)$ \\
\hline \multirow[t]{6}{*}{ Carbon monoxide } & 8 hours & 1 & 1 & $-b-$ \\
\hline & 1 hour & 5 & 1 & $-b-$ \\
\hline & 8 hours & 1 & 3 & $-b-$ \\
\hline & 1 hour & 5 & 3 & $-b-$ \\
\hline & 8 hours & 1 & 5 & $-b-$ \\
\hline & 1 hour & 5 & 5 & $-b-$ \\
\hline \multirow[t]{6}{*}{ Sulfur oxides } & 1 year & 1 & 1 & $-c-$ \\
\hline & 24 hours & 5 & 1 & $-c-$ \\
\hline & 1 year & 1 & 3 & $-c-$ \\
\hline & 24 hours & 5 & 3 & $-c-$ \\
\hline & 1 year & 1 & 5 & $-c-$ \\
\hline & 24 hours & 5 & 5 & $-c-$ \\
\hline \multirow[t]{6}{*}{ Nitrogen oxides } & 1 year & 1 & 1 & $-d-$ \\
\hline & 24 hours & 5 & 1 & $-d-$ \\
\hline & 1 year & 1 & 3 & $-d-$ \\
\hline & 24 hours & 5 & 3 & $-d-$ \\
\hline & 1 year & 1 & 5 & $-\mathrm{d}-$ \\
\hline & 24 hours & 5 & 5 & $-d-$ \\
\hline \multirow[t]{3}{*}{ Hydrocarbons } & 3 hours & 1 & 1 & $-e-$ \\
\hline & 3 hours & 1 & 3 & $-\mathrm{e}-$ \\
\hline & 3 hours & 1 & 5 & $-\mathrm{e}-$ \\
\hline
\end{tabular}

a Annual averages were based on the typical daily vehicular traffic. Shorter term averages were computed for a day on which heavy vehicle traffic also occurred. Wind-produced dust was included in the model.

b Regulatory levels are not reached. Maximum 1-hour and 8-hour concentrations at road edge are $0.52 \mu \mathrm{g} / \mathrm{m}^{3}$.

c Regulatory levels are not reached. Maximum 24-hour average concentration at road edge is $0.03 \mu \mathrm{g} / \mathrm{m}^{3}$. Maximum annual average concentration at road edge is $0.01 \mu \mathrm{g} / \mathrm{m}^{3}$.

d Regulatory levels are not reached. Maximum 24-hour average concentration at road edge is $0.06 \mu \mathrm{g} / \mathrm{m}^{3}$. Maximum annual average concentration at road edge is $0.01 \mu \mathrm{g} / \mathrm{m}^{3}$.

e Regulatory levels are not reached. Maximum 3-hour average concentration at road edge is $0.18 \mu \mathrm{g} / \mathrm{m}^{3}$. 


\subsubsection{Electricity Generators}

Because commercial electric power is not available at the ACF test arenas or at the Explosives Assembly Building, it is necessary to use electricity generators during test periods. Assuming that electricity would be generated for an average of 5 hours for each work day and that the total capacity of the generators is $100 \mathrm{~kW}$, then the annual electricity generation would be approximately $120,000 \mathrm{~kW}-\mathrm{hr}$.

These generators use diesel fuel. A $60 \mathrm{~kW}$ generator is located in the test arena area and a smaller unit is located at the Explosives Assembly Building. The production of air contaminants can be estimated using emission factors developed by the EPA (EPA, 1985, Table 3.4-1). These are summarized in Table 28. This table also contains the estimated annual emissions and the predicted concentrations of the contaminants. A method based on the kilowatt-hours generated was used. This method predicted annual emission of nitrogen oxides to be $1,796 \mathrm{~kg}$ (1.98 tons). The concentrations were predicted using INPUFF with a wind speed of $3 \mathrm{~m} / \mathrm{s}$ (10 fps). The values specified in the table for the average concentrations are the averages predicted at the Control Building with a steady wind from the generator area to the building.

Table 28. Emission Factors for Stationary Large-Bore Diesel Engines and Estimated Annual Emissions and Average Concentrations at the Control Building

\begin{tabular}{|lcccc|}
\hline Contaminant & $\begin{array}{c}\text { Emission Rate } \\
(\mathrm{g} / \mathrm{kW}-\mathrm{hr})\end{array}$ & $\begin{array}{c}\text { Total } \\
\text { Annual } \\
\text { Emissions }\end{array}$ & $\begin{array}{c}\text { Average } \\
\text { Concentration } \\
\left(\mu \mathrm{g} / \mathrm{m}^{3}\right)\end{array}$ & $\begin{array}{c}\text { Averaging } \\
\text { Period }\end{array}$ \\
\hline Nitrogen oxides & 15 & 1.98 & 2.3 & 24 hours \\
Carbon monoxide & 3.9 & 0.52 & 6.8 & 8 hours \\
Sulfur oxides & 1.7 & 0.22 & 4.3 & 3 hours \\
Particulates & 1.5 & 0.20 & 0.84 & 24 hours \\
Hydrocarbons & 0.44 & 0.06 & 1.2 & 3 hours \\
\hline
\end{tabular}




\subsubsection{Space Heating}

The two heated buildings associated with the ACF are Buildings 9831 (Control Building) and 9832 (Explosives Assembly Building). Building 9831 is heated with a 57,000 British thermal units per hour (BTU/hr) propane-fueled furnace. Building 9832 is heated with a $34,000 \mathrm{BTU} / \mathrm{hr}$ propane-fueled furnace. With the very conservative estimate of 40 percent duty cycle for these units throughout the year, the total heat requirement would be $3.2 \times 10^{8} \mathrm{BTU}$. The energy content of propane is approximately $95,550 \mathrm{BTU} / \mathrm{gallon}$ (gal), so these heating requirements imply consumption of approximately 3,400 gal of propane per year. Using standard EPA emission factors (EPA, 1985, Table 1.5-1), burning this quantity of propane would lead to the emission of air contaminants as summarized in Table 29.

Table 29. Air Contaminants Produced by Space Heating at the ACF

\begin{tabular}{|ll|}
\hline \multicolumn{1}{|c|}{ Contaminant } & $\begin{array}{c}\text { Production } \\
\text { (tons) }\end{array}$ \\
\hline Carbon monoxide & 0.005 \\
Nitrogen oxides & 0.02 \\
Hydrocarbons & 0.002 \\
Total & 0.027 \\
\hline
\end{tabular}

These quantities would be minimal. Cooling is provided using electrically powered cooling units which produce no air contaminants during operation; therefore, there would be no impact on local air quality.

\subsubsection{Solvents and Toxic Materials}

Small amounts of common highly volatile solvents such as alcohol and acetone would be used at the $\mathrm{ACF}$ for routine cleaning and degreasing. Maximum monthly consumption was estimated to be less than $10 \mathrm{~kg}(22 \mathrm{lb})$. This estimate was derived from data on the 
production of hazardous waste at the cable facility (SNNL, 1992). The monthly production of waste is typically 0.75 liter ( 0.9 quart) of liquid or about $1 \mathrm{~kg}(2.2 \mathrm{lb})$ of liquid solvent, and about $5 \mathrm{~kg}(11 \mathrm{lb})$ of solvent-soaked rags. At least half of the weight of the solvent-soaked rags would be the rag material. Therefore, the total amount of solvent in the waste stream would be about $3.0 \mathrm{~kg}(6.6 \mathrm{lb})$ per month. Assuming that 50 percent of the original solvent evaporates into the air during use, the monthly consumption would be $2 x(1 \mathrm{~kg}+1 / 2 \cdot 5 \mathrm{~kg})=7 \mathrm{~kg}$. The largest container would be limited to 3.8 liter (1 gallon) or approximately $3 \mathrm{~kg}(6.6 \mathrm{lb}$ ). Normal use of such materials would be spread throughout the month and so would result in minimal concentration in the air except within a very short distance from the use. However, an accidental spill could release up to the maximum quantity in a single container over a fairly short time. For the purpose of estimating the air quality implications of such a spill, it was assumed that $3 \mathrm{~kg}(6.6 \mathrm{lb})$ of material would be spilled, that the liquid would spread over an area of $4 \mathrm{~m}^{2}\left(43 \mathrm{ft}^{2}\right)$, that none of the spilled material would be recovered, and that the material would fully evaporate within one hour. If the spill occurred inside a building, it was assumed that personnel in the area would take immediate action to thoroughly ventilate and then leave the area unless equipped with appropriate protective gear. Because of the ventilation, the building would have little effect on the dispersion. The concentration of the vapor was estimated using the INPUFF model using a simulation of light and variable wind as described above. Under these conditions, the model predicts an average concentration of $10.1 \mathrm{mg} / \mathrm{m}^{3}$ at a distance of $10 \mathrm{~m}(32.8 \mathrm{ft})$ from the spill for the first hour after the spill. This value is well below the TWAs for common solvents as specified by the ACGIH (ACGIH, 1992). It must be noted that if such a spill occurred in an unventilated area, much higher concentrations could be reached. It also should be noted that many organic solvent vapors readily form explosive mixtures in air, and this hazard must be considered in the event of a spill.

\subsubsection{Magnesium Flares}

Up to 5 tests per year would involve the use of a single magnesium flare. Magnesium burns to produce primarily magnesium oxide with smaller quantities of magnesium nitride. Both of 
these materials are solid at normal temperatures; hence, the only air contamination that could result would be from the dispersal of small particles of these solid materials. The flares are designed so that the residue is cohesive and tends to remain in large pieces. It is estimated that less than 1 percent of the residue becomes airborne. The combustion of $5 \mathrm{~kg}(11 \mathrm{lb})$ of magnesium would produce approximately $8 \mathrm{~kg}(17.6 \mathrm{lb})$ of magnesium oxide and nitride. At a dispersal rate into the atmosphere of 1 percent, $80 \mathrm{~g}(0.18 \mathrm{lb})$ would become airborne. Very low concentrations would result from such quantities.

\subsection{AIR QUALITY SAFETY CONSIDERATIONS •}

Scenarios were developed to estimate the hazard radius and the minimum time until the test area can be safely re-entered after a test. Of the gaseous and particulate products of rocket motors, carbon monoxide ( $\mathrm{CO}$ ) is the controlling factor for estimating these quantities. Carbon monoxide is used as the controlling gas because the amounts of the other contaminants (sulfur dioxide and lead compounds) produced by the boosters are proportionally smaller compared with the amount of $\mathrm{CO}$ produced than the hazardous concentrations of these materials compared with the hazardous concentration of $\mathrm{CO}$.

A measure of a hazardous condition is the Short Term Exposure Limit (STEL). The STEL is the maximum 15-minute time weighted average exposure that should not be exceeded during the work day. However, the ACGIH no longer specifies an STEL for carbon monoxide so a different standard was adopted for the determination of the hazard radius and safe time until re-entry.

The Threshold Limit Value (TLV) for CO is $25 \mathrm{ppm}=28.6 \mu \mathrm{g} / \mathrm{m}^{3}$ (ACGIH, 1992). This value was used in the computations. The ACGIH recommended TLV is the time-weighted average concentration over the 8-hour work day and 40-hour work week that nearly all workers can be exposed to without adverse health effects. To apply the 25 ppm concentration to an averaging period of less than 8 hours would be to adopt an unrealistic and restrictive standard. 


\subsubsection{Hazard Radius}

For the purposes of this report, the air quality hazard radius is defined as the maximum distance from a test event at which the concentration of $\mathrm{CO}$ exceeds the TLV value on a 15-minute average basis rather than the 8-hour work day average. Light winds in a steady direction tend to produce higher concentrations at greater distances from the test event. However, the plume moves by any fixed position, so the average concentration produced by a transient event may not be particularly large. Light and variable winds tend to produce higher concentrations at nearby locations. Both wind scenarios were examined. Light and variable winds are very low in velocity and change frequently in direction. Such winds tend to keep the contaminants near their source. For the computations in this report, light and variable winds were approximated with a constant wind speed that changes direction by 90 degrees at 2-minute intervals. For this analysis, $0.5 \mathrm{~m} / \mathrm{s}(1.6 \mathrm{fps})$ winds were assumed. This wind speed is approximately $1 \mathrm{mi} / \mathrm{hr}$ and is the approximate threshold of response of most anemometers. The INPUFF dispersion model was used for the computations.

For rocket sled track operations using the expected maximum number of 11 Zuni rocket motors, the predicted distance from the test event at which the 15-minute average concentration of $\mathrm{CO}$ never exceeds $25 \mathrm{ppm}$ is 70 meters ( $230 \mathrm{ft}$ ). This occurs under the light and variable wind scenario. Under higher wind conditions, this hazard radius decreases rapidly. For boosted trolley operations using the expected maximum number of 25 Zuni rocket motors, INPUFF model calculations indicate that the ground level concentration of $\mathrm{CO}$ would never reach the level of $25 \mathrm{ppm}$ on a 15-minute average basis even with winds as light as $0.5 \mathrm{~m} / \mathrm{s}(1.6 \mathrm{fps})$. Therefore, 70 meters $(230 \mathrm{ft})$ is a good value to adopt for the air quality hazard radius. This safety radius is smaller than the Ground Hazard Area (GHA) of $305 \mathrm{~m}$ $(1,000 \mathrm{ft})$ used by the ACF to protect workers during rocket ignitions. 


\subsubsection{Elapsed Time Until Safe Re-entry}

For the purposes of this report, the safe time until re-entry into the test area is defined as the minimum time before the 15 -minute average $\mathrm{CO}$ concentration drops below $25 \mathrm{ppm}$ at all points within the test area. For computing the safe time until re-entry, the case that would lead to the longest times would be light and variable winds.

For $0.5 \mathrm{~m} / \mathrm{s}(1.6 \mathrm{fps})$ light and variable winds, using the scenario described above, the INPUFF model calculations indicate that the 15-minute average concentration is below $25 \mathrm{ppm}$ everywhere within the test area for the second 15-minute period after the test and all subsequent 15-minute periods. The actual area in which the concentration is above the $25 \mathrm{ppm}$ continuously decreases. It should be stressed that such light winds persisting for a time approaching a half hour would be quite unusual during normal working hours at the ACF. With wind speeds of $1.0 \mathrm{~m} / \mathrm{s}$ ( $3.3 \mathrm{fps}$ ) or higher, the 15 -minute average CO concentration will not exceed $25 \mathrm{ppm}$ anywhere within the test area.

For boosted trolley operations, as in the case of the hazard radius, the concentration does not reach $25 \mathrm{ppm}$ at ground level under any scenarios designed to simulate light and variable winds. Therefore, from the air quality point of view, it is safe to re-enter the test area immediately after a trolley event even if the maximum number of booster motors (25) has been employed.

\subsubsection{Recommendations for Protection of Human Health}

Given these air-modeling predictions, it is recommended that the following procedures should be adopted regarding re-entry into the test area after test events that have employed rocket sled track booster rockets: 
1. Monitor the winds at the test site during the testing and preparation period.

2. If the mean wind speed is less than $1.0 \mathrm{~m} / \mathrm{s}$ ( $3.3 \mathrm{fps}$ ), personnel would not be allowed to re-enter the area within $70 \mathrm{~m}(230 \mathrm{ft})$ of the rocket sled track for 15 minutes after a test.

3. If the mean wind speed equals or exceeds $1.0 \mathrm{~m} / \mathrm{s}(3.3 \mathrm{fps})$, no re-entry restrictions are necessary.

\subsection{CHANGES IN AIR QUALITY REGULATIONS}

The environmental consequences of the operation of the ACF have been evaluated in the context of current Federal, State of New Mexico, and local standards and regulations. The regulatory environment is dynamic, however. Changes in regulations must be tracked and appropriate procedural changes may need to be implemented to ensure continued compliance.

\subsection{SUMMARY OF AIR QUALITY IMPACTS AT THE ACF}

The air quality impact results from a wide variety of sources:

- Gaseous engine emissions of vehicles and generators;

- Fugitive dust from vehicles operating on unpaved roads;

- Fugitive dust from wind erosion of unpaved roads; and

- Gaseous and particulate matter emitted by booster motors and test ordnance.

All emission rates and maximum concentrations of particulates would be less than New Mexico standards except fugitive dust generated by vehicular traffic on unpaved roads. In a corridor up to $52 \mathrm{~m}$ (170 ft) wide centered on the road, the particulate concentration could exceed the ambient standard for particulates under $10 \mu \mathrm{m}$ in diameter. Over a wider corridor, the average concentration would not exceed the standard. This effect is dependent on wind conditions. With stronger winds, the width of the corridor with the concentration above the 
standard would be smaller. Unpaved roads are a significant source of particulates throughout the Southwest, and the roads at the ACF are no exception.

Table 30 summarizes the annual emissions of the various contaminants by the various processes. Table 31 summarizes the concentrations that result at the Control Building. The estimated maximum is not always the sum, because some processes are not concurrent.

Table 32 summarizes the total emission and maximum concentrations of air contaminants. For convenience, the New Mexico standards also are displayed in this table. The total emission of a given contaminant is the sum of the yearly emissions of all sources of that particular. material. The maximum concentration is the maximum concentration of a given pollutant that was predicted by the INPUFF or HIWAY2 dispersion model. As listed in this table, total emissions and approximately averaged concentrations are well below regulatory levels of concern.

Worker protection from airborne chemicals released by rocket motor firings can be assured if workers are not allowed to re-enter the area within $70 \mathrm{~m}$ ( $230 \mathrm{ft}$ ) of the test for 15 minutes after completion whenever the average wind speed is less than $1 \mathrm{~m} / \mathrm{s}$ ( $3.3 \mathrm{fps})$. Likewise, workers should avoid inhalation of the smoke plume from firing the 3-inch gun because of its lead content. Although it is unlikely that the recommended 8-hour TWA concentration would be reached, the exposure could exceed the recommended maximum for brief periods. 
Table 30. Total Annual Emissions of Atmospheric Contaminants

During ACF Operation

(tons)

\begin{tabular}{|lllllllll|}
\hline \multicolumn{1}{|c}{ Process } & $\mathrm{CO}^{\mathrm{a}}$ & $\mathrm{HC}^{\mathrm{c}}$ & $\mathrm{NO}_{\mathrm{x}}$ & $\mathrm{TSP}$ & $\mathrm{SO}_{\mathrm{x}}$ & $\mathrm{HCN}$ & $\mathrm{Pb}$ & $\mathrm{NH}_{3}$ \\
\hline Vehicles and Roads & 0.11 & 0.011 & 0.015 & 5.4 & 0.004 & & & \\
Generators & 0.52 & 0.06 & 1.98 & 0.20 & 0.22 & & & \\
Space Heating & 0.005 & 0.002 & 0.02 & & & & & \\
Boosters & 4.7 & & & $0.07^{\mathrm{b}}$ & 0.056 & & 0.007 & \\
Explosives & 0.52 & 0.088 & & 0.11 & & 0.018 & 0.004 & 0.019 \\
Total & 5.9 & 0.16 & 2.0 & 5.7 & 0.28 & 0.018 & 0.011 & 0.019 \\
\hline
\end{tabular}

a $\mathrm{CO}=$ carbon monoxide; $\mathrm{HC}=$ hydrocarbons; $\mathrm{NO}_{\mathrm{x}}=$ nitrogen oxides; $\mathrm{TSP}=$ total suspended particulates; $\mathrm{HCN}=$ hydrogen cyanide; $\mathrm{Pb}=$ lead; $\mathrm{NH}_{3}=$ ammonia

b Includes all nongaseous emissions

c Includes methane

Table 31. Maximum Concentrations of Atmospheric Contaminants During ACF Operation for Appropriate Averaging Periods at the Control Building $\left(\mu \mathrm{g} / \mathrm{m}^{3}\right)$

\begin{tabular}{|lcccccccc|}
\hline \multicolumn{1}{|c}{ Process } & $\mathrm{CO}^{\mathrm{a}}$ & $\mathrm{HC}^{\mathrm{c}}$ & $\mathrm{NO}_{\mathrm{x}}$ & $\mathrm{TSP}$ & $\mathrm{SO}_{\mathrm{x}}$ & $\mathrm{HCN}$ & $\mathrm{NH}_{3}$ & $\mathrm{~Pb}$ \\
\hline Vehicles & 0.52 & 0.18 & 0.06 & 1.3 & 0.03 & & & \\
Generators & 6.8 & 1.2 & 2.3 & 0.84 & 0.9 & & & \\
Space Heating & $<0.001$ & $<0.001$ & $<0.001$ & & & & & \\
Boosters & 14.6 & & & $0.22^{\mathrm{b}}$ & 0.47 & & & $0.00081^{\mathrm{d}}$ \\
Explosives & 14.8 & 2.6 & & 2.8 & & 0.50 & 0.54 & 0.00010 \\
Estimated Max. & 22.1 & 4.0 & 2.4 & 5.2 & 1.4 & 0.05 & 0.54 & 0.00081 \\
\hline
\end{tabular}

a $\mathrm{CO}=$ carbon monoxide; $\mathrm{HC}=$ hydrocarbons; $\mathrm{NO}_{\mathrm{x}}=$ nitrogen oxides; $\mathrm{TSP}=$ total suspended particulates; $\mathrm{HCN}=$ hydrogen cyanide; $\mathrm{Pb}=$ lead; $\mathrm{NH}_{3}=$ ammonia

b Includes all nongaseous emissions

c Includes methane

d Assumes 1/4 of tests involving rocket motors take place each calendar quarter 


\section{Table 32. Total Annual Emissions and Estimated Maximum Concentrations of Atmospheric Contaminants at the ACF Control Building During Operation of the ACF}

\begin{tabular}{|c|c|c|c|c|c|}
\hline \multirow[b]{2}{*}{ Contaminant } & \multirow[b]{2}{*}{$\begin{array}{l}\text { NM Significant } \\
\text { Emission Rate } \\
\text { (tons/year) }\end{array}$} & \multirow[b]{2}{*}{$\begin{array}{c}\text { NM Significant } \\
\text { Concentration } \\
\left(\mu \mathrm{g} / \mathrm{m}^{3}\right)\end{array}$} & \multirow[b]{2}{*}{$\begin{array}{c}\text { Averaging } \\
\text { Time }\end{array}$} & \multicolumn{2}{|c|}{ ACF Estimated } \\
\hline & & & & $\begin{array}{c}\text { Total } \\
\text { Emission } \\
\text { (tons/yr) }\end{array}$ & $\begin{array}{c}\text { Maximum } \\
\text { Concentration } \\
\left(\mu \mathrm{g} / \mathrm{m}^{3}\right)^{\star}\end{array}$ \\
\hline Carbon monoxide & 100 & 575 & 8 hours & 5.9 & 22.1 \\
\hline Hydrocarbons & 40 & $-b-$ & 3 hours & 0.16 & 4.0 \\
\hline Nitrogen oxides & 40 & 14 & 24 hours & 2.1 & 2.4 \\
\hline $\begin{array}{c}\text { Total suspended } \\
\text { particulates }\end{array}$ & 25 & 10 & 24 hours & $5.8^{\mathrm{f}}$ & 5.2 \\
\hline Sulfur oxides & 40 & 13 & 3 hours & $0.29^{c}$ & 1.4 \\
\hline Hydrogen cyanide & $-d-$ & $100^{\circ}$ & 8 hours & 0.18 & 0.50 \\
\hline Lead & 0.6 & 0.1 & 3 months & 0.011 & 0.00081 \\
\hline Potassium hydroxide & $-d-$ & $20^{e}$ & 8 hours & $0.063^{\mathrm{g}}$ & 0.16 \\
\hline Ammonia & $-d-$ & $180^{\circ}$ & 8 hours & 0.019 & 0.54 \\
\hline
\end{tabular}

a As predicted by INPUFF at the Control Building for $3 \mathrm{~m} / \mathrm{s}$ winds for the maximum concentration direction, except that total suspended particulates are predicted for $50 \mathrm{~m}$ from the road.

b No specific concentration specified. Three-hour significant ambient concentration in NM/AQCR 702 is $5 \mu \mathrm{g} / \mathrm{m}^{3}$.

c No acceptable monitoring technique is available.

d Not a criteria pollutant. No significant emission rate established.

e No concentration specified. The 8-hour limit is taken to be $1 / 100$ of the occupational exposure limit as specified in NM/AQCR 702.

- f Also includes maximum contaminant release scenario emission of nongaseous contaminants by booster rockets.

g Maximum contaminant release scenario emission. 
This page intentionally left blank. 


\section{REFERENCES}

ACGIH, 1992. Threshold Limit Values and Biological Exposure Indices for 1992-1993, Second Printing, American Conference of Governmental Industrial Hygienists.

Bickel, 1993, Information provided by David C. Bickel, SNL Organization 2735 to Kathy Gaither, SNL Organization, memorandum of 12 February 1993

Bohn, Russell, Thomas Cuscino, Jr., and Chatten Cowherd, Jr., 1978. Fugitive Emissions from Integrated Iron and Steel Plants. EPA Report 600/2-78-050.

Church, Hugh W., 1985. Canyon-Channeled.Wind, Sol 'se Mete Canyon, Sandia Report SAND85-2180 TTC-0702 UC-71.

DA, 1991. Aerial Cable Test Capability Final Environmental Impact Statement. Department of the Army, October 1991.

EPA, 1980. User's Guide for HIWAY-2: A Highway Air Pollution Model. Environmental Protection Agency PB80-227-556.

EPA, 1985. U.S. Environmental Protection Agency, AP-42, Vol. 1. Compilation of Air Pollutant Emission Factors, Fourth edition, September 1985.

Hohnstreiter, G. F., W. L. Uncapher, D. C. Bickel, M. S. Garrett, N. R. Kellner, and D. R. Schater, undated (but released in 1991). Package Testing Capabilities at Sandia National Laboratories, Sandia-National Laboratories, Albuquerque, New Mexico.

Hyde, David W., 1988. User's Guide for Microcomputer Programs ConWep and FunPro, Applications of TM5-855-1, "Fundamentals of Protective Design for Conventional Weapons." SL-88-1, Department of the Army, Waterways Experiment Station, Corps of Engineers, Vicksburg, MS.

NMED, 1994. State of New Mexico, Environmental Department, Air Quality Bureau, Ambient Air Quality Standards and Air Quality Control Regulations, as amended.

Peterson, William B., and Lee Lavdas, 1986. INPUFF 2.0: A Multiple Source Gaussian Puff Dispersion Algorithm User's Guide. EPA Report 600/8-86/024.

SNL, 1990. 1990 Environmental Monitoring Report. SAND91-0592, Sandia National Laboratories, Albuquerque, NM.

SNL, 1992. Activity Specific ES\&H Operating Procedure, Sol se Mete Aerial Cable Facility, SP472188. Sandia National Laboratories. 
This page intentionally left blank. 
DISTRIBUTION:

U.S. Department of Energy

Albuquerque Field Office

P.O. Box 5400

Albuquerque, NM 87185

Attn: J.F. Levings, ERPO, AL

C.L. Soden, EPD, AL

2

MS 0184 U.S. Department of Energy

Kirtland Area Office

Albuquerque, NM 87185

Attn: G.K. Laskar

S. L. Lacy

4

1

1

1

1

1

1

1

1

1

3

1

10

3

1

5

1

R. Cunniff

W. M. Gutman

Robert J. Silver

Physical Science Laboratory

Environmental Group

P.O. Box 30002

Las Cruces, NM 88003-0002

MS1135 D. C. Bickel, 2735

MS1135 M. S. Garrett, 2761

MS 1035 J. T. Baremore, 7200

MS 1037 A. O. Bendure, 7258

MS 1037 J. V. Guerrero, 7258

MS 1037 E. R. Withers, 7258

MS 1037 J. M. Harris, 7258

MS 1037 D. C. Nargelovic, 7258

MS 1037 T. Sanchez-Brown, 7258

MS 1061 T. A. Wolff, 7258

MS 1311 Su Hwang, 7575

MS 9018 Central Technical Files, 8523-2

MS 0899 Technical Library, 13414

MS 0619 Technical Publications, 12613

MS 0100 Document Processing for DOE/OSTI, 7613-2 